\title{
Proměny vztahů ruské pravoslavné církve a státu v době patriarchy Kirilla ${ }^{1}$
}

\author{
Transformations in the relationship between the Russian Orthodox Church \\ and the state in the times of the patriarch Kirill
}

MARia Avanesova, Vladimír NAXERA²

\begin{abstract}
This paper is devoted to the topic of relations between the Russian state, Russian society, and the Orthodox Church after the year 2008, when Patriarch Kirill was elected head of the Church. Such relations in Russia have gone through a significant transformation since the beginning of the Post-Soviet period. In the era of Patriarch Alexy II, the Church gradually began to claim a larger political role, the culmination of which was marked by Kirill's election. At present, the Russian Orthodox Church operates to a certain degree as an institution of Russian political power. Its representatives, led by Kirill, often play a role that is more political than religious. By drawing from primary sources, official documents, media reports, and also speeches made by religious and political representatives, this article attempts to highlight the main issues and areas of cooperation between the state and the Church (e.g. the education system, elections in 2011 and 2012) and explain the ways in which this alliance is advantageous for both parties in relation to the Russian public. The last part of the article deals with how this connection between church and state is perceived by various sections of the Russian public, which is illustrated using several examples from previous years, e.g. the scandal surrounding the members of the feminist punk rock protest group Pussy Riot.
\end{abstract}

Keywords: Russia; Orthodox Church; Patriarch; Kirill I; Alexy II; Putin

\section{1. Úvodem}

Vztah státu (respektive politické sféry) a církve patří mezi časté předměty politologických analýz. Existuje celá řada témat, která politická (respektive

1 Text je dílčím výstupem projektu „SGS-2016-030 Politický řád, legitimita politické moci a nastolování diskurzu: vybrané otázky aplikované politické teorie“, který byl poskytnut Západočeskou univerzitou v Plzni.

2 Bc. Maria Avanesova a PhDr. Vladimír Naxera, Ph.D., Katedra politologie a mezinárodních vztahů, FF ZČU v Plzni / Department of Politics and International Relations, Faculty of Philosophy and Arts, University of West Bohemia, Czech Republic. Contact: avanesov@students.zcu.cz (Maria Avanesova), vnaxera@kap.zcu.cz (Vladimír Naxera). 
obecněji sociálnî) věda, včetně té české, ve spojení s tímto vztahem zkoumá - at' už jde o otázku sekularizace (v českém prostředí např. Hanuš 2006), existenci politických stran spojených s nějakým náboženským či církevním principem (např. Fiala 2007), úlohu církví ve vnitrostátní i zahraniční politice (např. Kratochvíl 2011), roli Vatikánu v mezinárodních vztazích (nap̌r. Sekerák 2014) nebo postavení církve v komunistickém režimu (např. Balík a Hanuš 2013) a mnoho dalšího. Velice zajímavou otázkou je právě úloha církve v kontextu nedemokratického režimu. Do této oblasti zájmu politologie spadá i předkládaný text, který s konkrétním zaměřením na Ruskou federaci (dále též RF) posledních let zkoumá některé význačné aspekty vztahu státu a církve - konkrétně to, jakým způsobem jsou stát a církev v RF provázány.

Mezi všemi náboženstvími, která jsou v Rusku vyznávána, má nezpochybnitelně největší autoritu Ruská pravoslavná církev Moskevského patriarchátu (Russkaja pravoslavnaja cerkov’ Moskovskogo patriarchata, dále též RPC), protože spojuje (i když pouze nominálně) většinu obyvatel Ruska. Ruská pravoslavná církev je největší autokefální pravoslavnou církví na světě a podle průzkumu veřejného mínění se většina obyvatel Ruska řadí právě mezi příslušníky pravoslavné církve. Průzkumy WCIOM (Všeruské centrum výzkumu veřejného míněnî) ukazují, že v roce 2013 se k pravoslavné církvi hlásilo $77 \%$ obyvatel Ruska (WCIOM 2013a). Není sice pravděpodobné, že by většina obyvatel Ruska vnímala vystoupení náboženských vưdců jako apel $\mathrm{k}$ vlastní politické a společenské činnosti, což ale $\mathrm{v}$ zásadě neruší úctu $\mathrm{k}$ vyjádřením pravoslavných činitelů a uznání jejich autority. To se týká jejich působení jak v oblasti morálky, tak i v politické oblasti.

$\mathrm{V}$ ruské ústavě je zakotveno, že Rusko je světským státem, ${ }^{3}$ což ale neznamená, že se RPC nesnaží působit na společnost i v oblastech, které se primárně náboženství netýkajî. ${ }^{4}$ RPC se totiž zjevně snaží podílet na politice Ruska, což církvi umožňuje i ruská vláda, která má výraznou pro-pravoslavnou orientaci. Navíc podle průzkumů WCIOM (2013b) nemůže většina občanů Ruska ani přpustit, že by prezidentem země byl člověk, který by vyznával jiné náboženství než pravoslaví (nebo se nehlásil k žádnému vyznánî).

Vztahy mezi církví a státem na straně jedné a společností na straně druhé se od dob rozpadu SSSR výrazně proměnily. Bez ohledu na světský charakter Ruska a odluku církví od státu se během patriarchátu Alexije II. (ve funkci 1990-2008) zvyšoval politický význam patriarchy a církve jako celku. Docházelo k výraznému nárůstu vlivu RPC na politický proces $\mathrm{v}$ Rusku, zejména prostřednictvím aktivní spolupráce s oficiálními orgány státní moci, silové složky nevyjímaje. RPC začala

\footnotetext{
3 Článek 14 uvádí, že „1. Rusko je světský stát. Žádné náboženství nemůže být nastoleno jako státní nebo povinné. 2. Náboženské organizace jsou oddělené od státu a jsou rovné před zákonem“ (Ústava RF 1993: čl. 14).

${ }^{4}$ RPC se např́klad snaží být zdrojem státní ideologie (viz mj. Vyžukovič 2015). K tomu se v textu ještě vrátíme.
} 
zaujímat aktivní postoj ke všem politicky významným událostem a předkládat politické iniciativy. Tento posun stručně představíme níže. Po většinu postsovětského období patří RPC díky svým aktivitám k nejvýznamnějším vlivovým aktérům v rámci ruského autoritativního režimu. Postsovětské Rusko je ostatně běžně spojované s velkou úlohou nevolených aktérů, které politická věda často označuje jako poručnické síly (př́padně poručnické instituce nebo též organizace; viz např. Bílek 2015; Gilbertová a Mohseni 2011 a dalšî). Jde o takové nevolené aktéry, kteř́ zasahují do vzorců reprodukce moci, jež jsou jinak založené na existenci demokratických procesů (Bílek 2015: 129-130) ve smyslu zajištění alespoň základních principů soutěživosti voleb (nikoli nutně demokratičnosti systému jako takového ${ }^{5}$ ). Nejběžnějšími typy poručnických aktérů bývají síly armádní, monarchické nebo náboženské (Gilbertová a Mohseni 2011; srov. Bílek 2015).

V př́padě Ruska můžeme identifikovat činnost poručnických aktérů již od 90. let - zatímco v pŕípadě období prezidentství Borise Jelcina šlo zejména o tzv. Rodinu ${ }^{6}$ a důležité oligarchy, zejména tzv. „Velkou sedmičku“"7 (Holzer 2001: 115), za prezidentství Vladimíra Putina byl vliv oligarchů na politiku značně oslaben a do velké míry nahrazen vlivem tzv. silovikư, tedy aktérů vycházejících z prostředí bezpečnostních složek (Leichtová 2010: 110). Vedle těchto aktérů se další nevolenou silou s postupně rostoucím vlivem na společnost jak v době prezidenta Jelcina, tak po nástupu Putina stala RPC vedená patriarchou Alexijem II. Každý z těchto aktérů však vstupoval do politického procesu částečně odlišným zpơsobem - zatímco zejména ve druhém Jelcinově volebním období to byli právě oligarchové, kdo určoval velkou část politické agendy, jelikož oligarchové a Rodina ovlivňovali prezidenta a jeho nejblížší okolí a tvořili tedy pomyslné jádro rozhodovacího procesu (srov. např. Baturin et al. 2003), po nástupu Putina se vzorce distribuce moci proměnily. Centrem moci se jednoznačně stal prezident, který do mocenského okruhu nejbližších spolupracovníků a vlivných jedinců zahrnul velké množství siloviků. Ti sice stále mají značný vliv na rozhodovací proces, ale neovlivňují prezidenta tak, jak oligarchové ovlivňovali Jelcina. Zapojení církve je ještě odlišnější - církev a oficiální instituce spolupracují na základě principu vzájemné prospěšnosti.

\footnotetext{
5 O současném Rusku v žádném př́padě nelze hovořit jako o státu demokratickém - Putinův režim lze dle mnoha odborníků (např. Holzer 2015: 97) směle označit za režim autoritativní. Putin sám přitom povahu režimu zastírá koncepty tzv. řízené nebo též suverénní demokracie (mj. Leichtová 2010: 113-115), která má, namísto odmítaného západního modelu liberálně demokratického zřízení, být pro Rusko ideální cestou.

6 Jako Rodina se označovalo uskupen kolem Jelcina, do něhož kromě jeho dcery Tatiany Djačenko patřilo nejbližši Jelcinovo okolí, např. Boris Berezovskij, Roman Abramovič nebo Valentin Jumašev.

7 Tzv. Velká sedmička, též skupina semibankirščiny - termín označoval sedm bankéřů, kteří kontrolovali více než $50 \%$ ruské ekonomiky a v značné míře ovlivňovali politiku prezidenta Jelcina.
} 
I když církev získala značnou politickou úlohu již za patriarchátu Alexije II., po nástupu patriarchy Kirilla (občanským jménem Vladimíra Gund’ajeva) do úřadu můžeme zaznamenat další posílení politické úlohy RPC. Cílem předkládaného textu je zmapovat podobu vztahů církve a státu po zvolení Kirilla moskevským patriarchou a zjistit, v jakých oblastech především dochází ke spolupráci mezi církvi i a státem a jeho institucemi a představiteli. ${ }^{9}$ Naše hlavní výzkumná otázka zní, jakémi aprisoby církev posiluje a upevñuje svoje společenské a politické postavení, respektive jakým apuisobem v tomto obledu cirkvi napomáhá stát. Kroky k posílení tohoto postavení totiž podniká jak církev, tak stát, přičemž tyto kroky bývají často vzájemně provázané. $V$ předkládaném textu nám půjde o témata jako volební podpora vyjadřovaná ze strany církve politickým př́edstavitelům, legitimizace kroků politické moci ze strany církve nebo vytváření diskurzu, který vysvětluje a za pomoci historických a „civilizačních“ argumentů ospravedlňuje úzkou vazbu církve a státu, stejně jako skutečnost, že se oba aktéri výrazně ovlivňují. Jejich vzájemná spolupráce je přitom oboustranně výhodná - církevní podpora pomáhá legitimizovat často diskutabilní kroky vlády ruského autoritativního režimu, za tuto podporu má církev na oplátku umožněn privilegovaný př́stup do společnosti v podobě pronikání do školství a médií a celkově $\mathrm{v}$ podobě privilegování pravoslavného vyznání před těmi ostatními. Aktivita vedoucí od církve $\mathrm{k}$ podpoře státu se tedy vzápětí přetavuje do zpětné podpory od státu vưči církvi.

Nicméně přes oboustrannou výhodnost tohoto vztahu lze konstatovat, že v něm spíše dominuje světská moc (což je ostatně pro tzv. symfonii moci historicky běžné - viz níže); RPC je také jedním z důležitých nástrojů Putinovy vlády, který zajišt'uje legitimitu režimu a podporu ruských věřících politické sféře. Zároveň však nemůžeme tvrdit, že by církev nebyla autonomní institucí, která veškerou svojí aktivitu odvijí od požadavků státu, jemuž by zcela podléhala takový výklad by rozhodně nebyl přesný, jelikož impulsy k celé řadě společenských a politických aktivit vycházejí právě z církve, nikoli od státu. $\mathrm{Na}$ druhou stranu je (jak si v textu ukážeme) zjevné, že církev je do pozice schvalovatelky a podporovatelky kroků Kremlu režimem a systémem vzájemné prospěšnosti do velké míry tlačena. Místo RPC v politickém systému je tedy neoddiskutovatelné, a to je také hlavním důvodem zvolené perspektivy tohoto

\footnotetext{
8 Již zde je třeba poznamenat, že pokud v textu hovoříme o církvi, respektive o postojích církve, máme na mysli nejvyšší pozice v církevní hierarchii, případně oficiální názor církevního vedení. Jsme si prritom vědomi skutečnosti, že řada aktérů na nižších úrovních (řadoví duchovní, představitelé církevních obcí, klášterů atd.) může mít a často i má odlišný názor, který je ovšem do velké míry církevním vedením upozaděn. Zajímat nás budou tedy ve většině př́padů postoje vysokých představitelů a zejména patriarchy, který církev do velké míry personifikuje.

9 Text se zaměřuje spíše na vnitropolitické procesy; zahraničněpolitickým jevům, které by vydaly na samostatnou studii, je věnována okrajová pozornost, byt' i v tomto př́padě vliv a propojení naznačujeme.
} 
textu, jenž se na vzájemný vztah zaměřuje převážně z pohledu církevního: Soustředíme se tedy na to, co do daného vztahu vnáší církev (at' už v podobě podpory nebo požadavků, či obecně témat $\mathrm{k}$ řešení). Alespoň naznačena však v textu musí být i opačná perspektiva, tedy to, jak konkrétně využívá stát, respektive Putinův režim církev pro své fungování.

Než se však začneme věnovat Kirillovi, je třeba alespoň v několika odstavcích načrtnout vývoj vzájemných vztahů státu a církve před nástupem Kirilla do funkce patriarchy. Půjde nám jak o historickou dimenzi, tak zejména o posun, kterým tyto vztahy prošly v době patriarchy Alexije II. (1990-2008). Kirill totiž nepřebíral vedení církve „ve vzduchoprázdnu“ a domníváme se, že předchozí kontext výrazně ovlivňuje současné dění. Pasáže věnující se období před Kirillem tudíž nelze považovat za samoúčelné.

Dané téma, tedy vztah RPC a státu v postsovětském Rusku, je v české odborné tvorbě zpracované pouze okrajově a neexistuje př́liš původních českých děl ani přkkladů děl zahraničních. To se netýká pouze nejnovějšího období Kirillova patriarchátu, ale i let předchozích, která byla spojená s patriarchou Alexijem II. ${ }^{10}$ Práce je proto založena především na zdrojích ruských, prričemž jádrem jsou zejména zdroje primární (i z toho důvodu, že ruské odborné produkce, jež by si od tématu dokázala držet kritický odstup, není k dispozici mnoho). Analyzovaný korpus pramenů obsahoval jednak státní dokumenty upravující fungování církvem tak oficiální církevní dokumenty a předpisy, ale zejména všechny dohledaná vyjádření církve a jejích představitelů (mediální sdělení, blogy představitelů atd.) pronesená $\mathrm{v}$ reakci na $\mathrm{v}$ textu zmiňované události. Za zásadní považujeme zejména tyto prameny vycházející př́mo z prostředí církevních funkcionářu, jelikož velká část naší studie je vystavěna právě na analýze rozhovorů, blogů funkcionářù a podobně.

\section{Specifika ruské pravoslavné církve a náčrt vývoje jejího vztahu se státem do nástupu patriarchy Kirilla}

Dějiny ruské pravoslavné církve a jejîho vztahu se státem jsou dějinami výrazných specifik. Ve srovnání s těmi evropskými zeměmi, které přijaly západní podobu křest’anství, vykazuje Rusko jasné odlišnosti, jelikož vztah státu a „západni“ víry na straně jedné a státu a pravoslaví na straně druhé je zcela jiný (Besançon 2015). Christianizace Ruska se tradičně spojuje s rokem 988, kdy byl pokřtěn kníže Vladimír (srov. Boček 2011), později svatořečený. Kyjevský metropolita, který byl hlavou církve na Rusi a který později přesídlil do Moskvy, byl zprvu pod vlivem konstantinopolského patriarchy. Narušení této závislosti nastalo v roce 1448, kdy

10 Oproti tomu $\mathrm{v}$ historické perspektivě minulých staletí je tento vztah českými akademiky zkoumán poměrně často. 
byl metropolita zvolen bez souhlasu patriarchy. Vlastní patriarchát získala Rus roku 1589.

Církev, nyní již ryze ruská, však neměla na nezávislý vývoj mnoho času, jelikož o sto let později se dostala do jiné závislosti - totiž na státu. Patriarcha Nikon zahájil v polovině 17 . století reformy, které měly mimo jiné nadřadit důležitost patriarchy carskému majestátu. $\mathrm{V}$ důsledku této snahy byl Nikon roku 1666 sesazen a poslán do vyhnanství (Lobačev 2003: 26). Toto můžeme považovat za osudovou křržovatku ruského pravoslaví, které bylo připoutáno blíže státu. Další zásadní změny nastaly po roce 1700 , kdy zemřel patriarcha Adrian, po jehož smrti Petr I. nejmenoval nového patriarchu, ale pouze exarchu jako církevního správce, a roku 1721 úrad patriarchy zrušil úplně - na jeho místo byl jmenován Nejsvětější vládnoucí synod jako kolektivní těleso, jehož členové byli dosazováni carem. Z církve se de facto stala součást státní správy, která zcela (personálně, finančně, organizačně) podléhala carské vládě. Je zřejmé, že tento vývoj odlišuje Rusko od států západní i střední Evropy. Zrušení autonomie církve přitom neznamenalo potlačení významu pravoslaví, které se v následujících staletích stalo základem ideologie samoděržavného státu - ta byla postavena na známém hesle ideologa režimu hraběte Sergeje Uvarova: „samoděržaví pravoslaví - národnost“. Pravoslaví bylo tedy již carskou vládou považováno za zásadní součást ruské národní a státní identity.

Úřad patriarchy byl obnoven až v průběhu roku 1917, nicméně následující bolševická revoluce a vývoj $\mathrm{v}$ dalších letech měly za následek ještě pevnější podřízení církve státu, než tomu bylo $\mathrm{v}$ době posledních carů. Změna nastává až ke konci vlády Michaila Gorbačova. Když byl roku 1990 zvolen do funkce patriarcha Alexij II., šlo teprve o druhého patriarchu v dějinách RPC, do jehož volby výrazněji nezasahoval stát. Zároveň byl po Nikonovi prvním patriarchou, kterému se podařilo sbližit představitele církve a státu i jejich zájmy (viz napřr. Knox 2005: 170-172).

I když na začátku 90. let fungovaly církev a stát do velké míry jako nezávislí aktéri a rétorika státu zůstávala víceméně v rovině omluv církvi za její postavení $\mathrm{v}$ předchozích desetiletích, což bylo doprovázeno otevíráním nových chrámů a monastýrů, vznikem nových církevních obcí a podobně, velice brzy se začaly vzájemné vztahy proměňovat. Od počátku existence nového ruského státu si církev nárokovala vliv na společnost a patriarcha církev stylizoval do role aktéra, který má společnost nacházející se v komplikované postkomunistické situaci, spojené s hledáním vlastní nové identity, ekonomickým úpadkem a úpadkem prestiže celého státu, pomoci stabilizovat. Ruské pravoslaví nabídlo novou konzistentní sadu hodnot a idejí, která mohla vyplnit normativní vakuum vzniklé nedávným zavržením komunismu. Ostatně v tomto, tedy ve vytvoření jakési nové 
národní/státní ideologie, ${ }^{11}$ byla církev podporovaná státem a Alexij II. často opakoval, že v Rusku existuje historická tradice, díky které je pravoslaví jedním z pilírú ruské státnosti (Ridiger 1995: 9-13). Ze strany Alexije II. tedy od počátku zazníval apel $\mathrm{k}$ návratu $\mathrm{k}$ těmto historickým tradicím, který byl zároveň do velké míry doprovázený odporem k prijímání hodnot západních - ve většině projevů byl Západ pojímán jako nositel negativních hodnot, které by Rusko nemělo přebírat. V tomto ohledu se patriarchův postoj podobal postoji řady vlivných intelektuálů (typicky např. Solženicyn 1995). Po krátkém počátečním období tedy nastal stav, ve kterém se z církve stávala státem podporovaná instituce, která symbolizuje ztělesnění ruských hodnot, identity a ruské jedinečnosti oproti Západu. Pravoslaví tedy rychle dostalo politický náboj, církev a stát se postupně provázaly a poslání církve se vedle náboženského záhy stalo také společenskopolitickým.

Alexij II. také rychle prrivedl církev ke spojenectví s politickou mocí. V roce 1993 pomohl prezidentovi legitimizovat použití násilí vůči rebelujícímu parlamentu, v roce 1996 v průběhu prezidentské volby otevréeně podpořil Jelcina, a to ještě $\mathrm{v}$ době, kdy bylo jeho opětovné zvolení díky výrazně nízké popularitě zcela nejisté (Holzer 2001: 41). ${ }^{12} \mathrm{~V}$ prezidentské volbě v roce 2000 se patriarcha výrazně angažoval v propagaci kremelského kandidáta Putina; osobně pak požehnal na bohoslužbě vedené u př́ležitosti jeho zvolení (Bičurin 2000). Putina podpořil i v následující volbě, stejně tak v roce 2008 dalšího kremelského kandidáta Dmitrije Medveděva. Kromě kremelských kandidátů církev úzce spolupracovala i s dalšími politickými proudy - podporu jí zejména v 90. letech vyjadřovala hlavně komunistická strana, ale také liberální demokraté a strany ruských nacionalistů. Vztah s těmito stranami, zejména komunisty a Jablokem (viz Holzer 2004), se začal zhoršovat po nástupu Putina do funkce prezidenta.

Po své smrti v roce 2008 byl Alexij II. tehdejším premiérem Putinem označen za důležitého státního (tedy nikoli církevního) činitele, který se zasloužil o postkomunistickou státnost Ruska (NTV 2008). Navzdory v ústavě zakotvené sekulární povaze Ruska se z patriarchy stal důležitý aktér nejen v duchovní, ale i ve společenské a politické sférée. Podle průzkumů veřejného mínění patřil Alexij II. mezi deset nejvýznamnějších politických aktérů země, polovina Rusů se také domnívala, že patriarcha hrál významnou politickou roli (FOM 2008).

Z období Alexije II. musíme zmínit ještě jednu událost, která se výrazně podepsala i na období Kirillova patriarchátu. Jde o přijetí federálního zákona

\footnotetext{
11 Pojem ideologie chápeme obecně ve smyslu konceptu označujícího národní, respektive státní myšlenku či ideu, která má být základem identity národa/státu; nejde tedy o striktní pojetí ideologie, s jakým v rámci konceptualizace nedemokratických režimů pracuje např́klad Juan J. Linz (2000; srov. také Ptáčník 2012).

12 To vše navzdory skutečnosti, že v roce 1994 přijal Biskupský sněm rozhodnutí, že církev a její představitelé nesmí vyjadřovat volební podporu žádným stranám ani kandidátům (RPC MP 2009a).
} 
o náboženské svobodě a náboženských organizacích ve druhé polovině 90 . let. Tento zákon nahradil zákon z roku 1990 a byl přijat za prrímého lobbování ze strany patriarchy Alexije II. (Semjonov 2012: 144): Zákon z roku 1990 totiž nevyhovoval církevním potřebám, nebot' otevíral prostor pro existenci sekt, které byly v Rusku po rozpadu SSSR velice populární. Snaha RPC ovlivnit situaci ve svůj prospěch byla zcela zřejmá - v souvislosti s nevelkou potřebou Rusů obracet se $\mathrm{k}$ tradičnímu náboženství místo sekt si církev mohla výraznější postavení ve společnosti v 90. letech zajistit jen jako státní náboženství. Proto ihned v roce 1993 začala kampaň za př́ijetí nového zákona, ale politická situace v Rusku tento problém odsunula do pozadí. Problém se znovu objevil v roce 1997, když byl návrh zákona předložen poslancem za komunistickou stranu V. Zorkal'cevem (Krasikov 2000: 235). Tento návrh obsahoval normy znevýhodňující všechny konfese kromě pravoslaví a byl vetován prezidentem Jelcinem (Knox 2005:170172). Ten vetování zákona vysvětloval porušením šestnácti článků ruské ústavy a dvou článků Všeobecné deklarace lidských práv, článků 18 a 19 Mezinárodního paktu o občanských a politických právech a článků 9 a 10 evropské Úmluvy o ochraně lidských práv a základních svobod (Krasikov 2000: 236). Nicméně za dva měsíce Jelcin tento dokument po de facto kosmetických změnách podepsal (Reisinger, Hesli a Erdem 1999: 42). Změnu názoru hlavy státu způsobila silná kampaň na podporu zákona, která byla zahájena představiteli ruské pravoslavné církve a částí politické elity, včetně tzv. skupiny semibankirščny, kteř́ chtěli církev využít jako základ pro novou ruskou státní ideologii (Krasikov 2000: 237) - církev a oligarchové se v tomto př́padě projevili jako velmi silní vlivoví aktéŕi. Konečná verze zákona přidělila pravoslaví výjimečnou roli (Reisinger, Hesli a Erdem 1999: 44), čímž církvi připravila dobré výchozí pozice pro politickou a společenskou činnost v dalším období. Zákon vyvolal nespokojenost na Západě, kde jej odsoudila řada př́edstavitelů (Sebencov 1998: 45), avšak umožnil církvi legitimizovat vlastní činnost $\mathrm{v}$ různých sférách života společnosti. V současnosti RPC tento zákon aktivně využívá.

\section{Vztahy RPC a státu v době Kirillova patriarchátu}

\section{a. Nástup patriarchy Kirilla do úřadu}

Zvolení Kirilla, metropolity smolenského a kaliningradského, zkušeného církevního diplomata, který byl již od 90 . let známý svými velmocenskými ${ }^{13}$ a mesiášskými myšlenkami a touhou posílit církevní vliv na společnost a politiku, do funkce patriarchy odpovídalo nejen snahám většiny představitelů církve o aktivnější pronikání RPC do politiky a veřejného života, ale i záměrům Kremlu.

13 Např. na konferenci náboženských vůdců před summitem G8 v roce 2007 Kirill ve svém prohlášení podpořil zahraniční politiku Ruska vůči systému americké protiraketové obrany (Gund'ajev 2007). 
Již podle předvolebních prríprav, jež zahrnovaly shromažd’ování a zveřejňování kompromitujících materiálů, bylo patrné, že celý proces voleb bude připomínat spíše světskou volební kampaň (Taratuta 2009a: 6). ${ }^{14} \mathrm{~V}$ boji o post patriarchy byl Kirill od počátku favoritem, protože byl jednak na rozdíl od svého hlavního konkurenta $\mathrm{v}$ ruské společnosti dobře znám, v neposlední řadě díky svým kázáním v sobotním televizním programu „Slovo pastýře“" (Slovo pastyrja) vysílaném na prvním kanálu, a jednak měl tichou podporu Kremlu. Ta se stala patrnou díky složení místního sněmu, který je společně s biskupským sněmem a Posvátným synodem jedním z nejvyšších orgánů RPC a jehož většinu členů z řad laiků tvořili představitelé moci a byznysu (Krug 2009; Taratuta 2009b: 6). Ti byli zároveň členy strany Jednotné Rusko a netajili se tím, že budou hlasovat pro Kirilla, protože si mysleli, že je podporován vedením strany a státu (Vedomosti 2009). Ze dvou kandidátů ucházejících se o post se Kirill hodil Kremlu více, protože jeho názory ohledně odmítání lidských práv, demokracie, západních modelů rozvoje státu a podpory ekumenismu umožňovaly legitimizovat $\mathrm{v}$ očích veřejnosti nastolený politický systém, který stále méně odpovídal demokracii deklarované v ústavě, a zároveň umožňovaly prostřednictvím církve posílit zahraničněpolitický vliv Ruska.

Kirill se stal 16. představeným RPC 1. února 2009, když vyhrál s obrovskou převahou (506 hlasů), jeho hlavní konkurent metropolita Kliment dostal 169 hlasů (Velikanov 2009: 23). Žrejmé zapojení státu do zvolení „patriarchy reformátora“"15 vyvolalo u ruské veřejnosti a představitelů i mezi zahraničními pozorovateli nejednoznačnou reakci týkající se očekávání vztahu patriarchy (respektive církve) a státu. ${ }^{16}$ Ke zvolení Kirillovi ihned pogratulovali prezident Medveděv a premiér Putin a také vyjádřili naději, že se dialog mezi pravoslavnou církví a státem bude dále rozvíjet (Borisov, Brynceva a Zaripova 2009). V rámci této posílené spolupráce se mimo jiné za Kirillova patriarchátu premiér či prezident častěji objevují na každoročních biskupských sněmech.

\footnotetext{
14 V ruském prostředí známý duchovní Andrej Kurajev srovnával volby patriarchy s ruskými světskými volbami z roku 1996 (Taratuta a Korobov 2008: 1).

15 Takový názor prezentovali např. Čaplin (2009) nebo Vološin a Blochin (2009). Existovaly ale i opačné názory, pro více informací viz např. Nižegorodcev (2009). Sám Kirill také odmítal, že je reformátorem (Byčkova, Kurajev, Smirnov a Ščipkov 2009).

${ }^{16}$ Např́ḱlad geopolitik Alexandr Dugin, který měl v dané době blízko kremelským postojům (viz např. Kalinič a Naxera 2011), tvrdil, že církev začíná novou, ovšem nikoliv ideologickou etapu. Kirill měl dle Duginova očekávání aktivně hájit pravoslavné hodnoty ve společnosti tím, že RPC bude aktivně bojovat s postmodernismem, liberální kulturou a liberálním egoismem (Taratuta a Korobov 2009: 6), tedy s hodnotami, za jejichž nositele bývá obecně považován Západ. Kirillovo zvolení bylo komentováno i za ruskými hranicemi. Např́klad polský deník Rzeczpospolita (v kontextu průběhu volby možná poněkud překvapivě) očekával, že Kirill nebude pouhým vykonavatelem kremelských pokynů, ale spíše půjde o aktivní spolupráci mezi církví a státem jako mezi dvěma partnery (Prus 2009).
} 
Kirill zdědil po Alexiji II. několik (z církevního pohledu) ožehavých, ale nevyřešených problémů. $K$ nim naprŕklad patřilo proniknutí RPC do oblasti vzdělávání nebo restituce církevního majetku, která bez ohledu na veškeré sliby státu fakticky neproběhla. RPC se potýkala s problémy jurisdikce voblasti postsovětského prostoru. Během Kirillova vládnutí se nejenže daří většinu těchto otázek postupně vyřešit, ale je též nastolována celá řada nových důležitých témat.

\section{b. Vztahy církve, státu a společnosti}

Již v prvních měsících po nástupu Kirilla začalo docházet $\mathrm{k}$ dalšímu aktivnímu sbližování RPC a federální vlády. $\mathrm{V}$ téže době se podle některých názorů patriarcha začal Kirill čím dál více stávat spíše politickým než církevním činitelem (Malašenko 2011). ${ }^{17}$ Touha patriarchy Kirilla plně kontrolovat situaci uvnitř církve jej prrivedla $\mathrm{k}$ zavedení propracované kádrové politiky, díky níž všechny důležité pozice obsadili lidé blízcí patriarchovi ${ }^{18}$ a všechna církevní oddělení začala vyžadovat, aby s nimi jim podřizené instituce projednávaly všechny své aktivity. Jedinci, kteří nesouhlasili s novou politikou patriarchátu, byli propuštěni, což vedlo $\mathrm{k}$ tomu, že Kirillova „reforma“ místo otevřenosti a svobody přinesla pouze pocit strachu (Solodovnik 2013: 14-17).

Dalším směrem ve strategii nového patriarchy se stalo aktivní silnější začlenění církve do společenského a politického života. Kirill ještě jako hlava oddělení vnějších církevních vztahů prohlašoval, že za nejlepší princip považuje tzv. „symfonii mezi státem a církví““ ${ }^{19}$ Takový názor vysvětloval tím, že carství a svátost jsou stejné boží dary (Gund’ajev 2005). A právě za Kirilla je taková spolupráce nejvíc patrná: Církev je aktivnější než v období Alexije II., navíc je podporovaná ze strany státu. Téměř bezprostředně po nástupu Kirilla došlo $\mathrm{k}$ jeho schůzce s ruským premiérem Putinem, ministrem kultury Alexandrem Avdějevem a vedoucím Rosimušcestva Jurijem Petrovem, což pomohlo výrazně urychlit vyřešení dlouhotrvající otázky restitucí církevního majetku. ${ }^{20}$ Zákon

17 Některé zdroje dokonce uváděly, že by se Kirill v roce 2011 mohl stát třetím členem tandemokracie (tandemocracy) Putin-Medveděv (Papkova 2011: 677).

18 Taková situace je pro RPC úplně nová, ale je obvyklá pro ruskou světskou moc. Něco obdobného se odehrálo po zvolení Putina, kdy všechny důležité mocenské pozice obsadil „Pitěrský klan“, nebo ve způsobu rozdělování míst na ruském ministerstvu obrany pod vedením Anatolije Serd'ukova.

19 Podstatou rusko-byzantského ideálu symfonie moci je sice vzájemná spolupráce, vzájemná podpora a vzájemná odpovědnost bez vniknutí jedné strany do výlučné pravomoci druhé (Džorajeva 1997: 39), ale v historické perspektivě je zřejmé, že moc světská měla v rámci této spolupráce, připomínající model caesaropapismu, vždy navrch.

${ }^{20}$ Oficiálně v ruském prostředí nikdo nikdy nemluvil o restituci. Tento termín je používán pouze v masmédiích (např. Kirillov 2007; Vedomosti 2010). Otázka restituce byla pro RPC ožehavá již od 90. let. V roce 1993 byl vydán výnos prezidenta RF, který doporučoval vládě RF připravit postupné předání budov a jiných nemovitostí, která mají náboženský účel, náboženským organizacím do vlastnictví nebo používání (Výnos Prezidenta RF 281-rp/1993), pak byla 
o převodu majetku pro náboženské účely byl podepsán prezidentem Medveděvem již v listopadu 2010. Podle zákona mají náboženské organizace kromě nároku na pozemky a nemovitosti také právo nárokovat objekty umění jako napríklad ikony nebo církevní nádoby (Federální zákon RF 327-FZ/2010). Reakce společnosti nebyla ale úplně kladná a v Moskvě, Voroněži, Čeljabinsku, Rjazani a Kaliningradě ${ }^{21}$ proběhla řada protestních akcí (Korobov et al. 2010: 5). ${ }^{22}$

Církvi bylo dále usnadněné pronikání do školství, což je patrné ze skutečnosti, že po nástupu Kirilla byl zaveden školní předmět „Základy pravoslavné kultury“ (Osnovy pravoslavnoj kultury), který si zaslouží zvláštní zmínku, protože jeho vyučování fakticky porušuje federální zákon o náboženské svobodě a náboženských organizacích (Federální zákon č.125/1997). Od roku 2006 předmět existoval jen jako experimentální (Interfax 2009), ale i tak vyvolal nespokojenost u ruských akademiků, jejichž pozice byla vyjádřena v dopisu deseti akademikư $^{23}$ (Novaja Gazeta 2007). Následně i prezident Putin přiznal, že takový předmět může existovat, ale pouze jako nepovinný (Regions.ru 2007), nicméně už v roce 2009 prezident Medveděv podpořil zavedení předmětu jako povinného (Antipova a Klin 2009). „Základy pravoslavné kultury“ se staly v roce 2010 spolu s předměty „Základy buddhismu“, „Základy islámu“, „Základy judaismu“ a „Světská etika“" v devatenácti regionech Ruska součástí povinného bloku pro vyučování na základní škole. Silná kritika ze strany experů byla vznesena vưči učebnicím, které měly být pro tyto kurzy využívány. Např́iklad učebnice světské

podepsána ještě celá řada vyhlášek, ale fakticky se do roku 2009 skoro nic nedělo. V roce 2008 patriarcha Alexij II. prohlásil, že RPC nenastolí otázku provádění restitucí, ale vítá kroky státu při navrácení církevních budov (RPC MP 2008). Ihned po nástupu Kirilla se však v ruských masmédiích objevila informace, že se chystá zákon o restitucích (Korobov 2009).

${ }^{21}$ Nejzajímavější situace s restitucí církevního majetku nastala v Kaliningradské oblasti, která byla před rokem 1945 součástí Východního Pruska. Do vlastnictví RPC byly v rámci restituce předány katolické a protestantské budovy, které nikdy neměly žádný vztah k pravoslaví. Některé z budov byly před převodem opraveny a farnosti investovaly do jejich oprav značné náklady. Kromě toho byly ruské pravoslavné církvi předány nejen církevní stavby, ale také staré obecní domy, zríceniny hradu nebo pozemky, na kterých kdysi náboženské stavby stály (KPRU 2010). Taková činnost porušovala zákon a právo protestantských a katolických náboženských organizací.

22 To vyvolalo nejednoznačnou reakci ve společnosti mimo jiné i proto, že církev v roce 2010 nebyla tak chudá jako dřive. V 90. letech bylo RPC dovoleno vyvážet 8,5\% celoruského objemu ropy (ISR 2050 nedat.). Navíc se církev pohybovala v prostředí byznysu jako zkušený hráč, naučila se řešit své „dočasné přebytky“ umístěním na vkladové účty, nákupem krátkodobých státních dluhopisů a dalších cenných papírů (Solodovnik 2013:19).

${ }^{23}$ Dopis vyjadřuje znepokojení stále sílící klerikalizací ruské společnosti, pronikáním církví do všech oblastí veřejného života, zejména do státního vzdělávacího systému. Ve svém dopisu akademici zdůraznili, že nebojují s náboženstvím a respektují city věřících, avšak nemohou zůstat lhostejní, pokud jsou činěny pokusy zpochybnit vědecké poznatky a nahradit znalosti vírou (Novaja Gazeta 2007). Obavy z klerikalizace vzdělání vyvolalo v ruské společnosti i vydání učebnice biologie pro světské školy S. Vertjanova, ve které je např́klad, „prováděna pravoslavná analýza řady biologických otázek“ (Vertjanov 2012: 2) a jedna kapitola je věnována plánu stvoření světa Bohem (Vertjanov 2012: 211-220). 
kultury podle expertizy Ruské akademie věd propagovala nejen pravoslaví, ale zároveň i náboženskou doktrínu, která vede k požadavku nahrazení kultury vírou (Zubec 2010). Přestože v roce 2009 prezident Medveděv zdůraznil, že psát učebnici a vyučovat předměty $\mathrm{z}$ daného bloku by měli pouze světští učitelé (Antipova a Klin 2009), učebnici „Základů pravoslavné kultury“ napsal prodiákon Kurajev, který je nejen aktivním duchovním, ale v té době byl znám i svými skandálními vystoupeními vůči nepřátelům patriarchy Kirilla a kritikou islámu. Jeho učebnice byla kritizována v oficiální recenzi Ruské akademie věd kvưli tomu, že neseznamuje žáky s pravoslavnou kulturou, ale s pravoslavnou náboženskou doktrínou, kterou jim násilně vnucuje (Ryžakov et al. 2009). Důležité je zdůraznit, že učebnice základů ostatních konfesí nebyly napsány současnými náboženskými činiteli těchto konfesí. Ale bez ohledu na výše uvedené výhrady je od roku 2012 je tento blok předmětů (společně s nově doplněným kurzem „Základy světových náboženských kultur") povinným pro všechny regiony Ruska, ${ }^{24}$ přičemž učebnice změnou neprošly. I přes zavedení předmětu dal patriarcha během svého vystoupení ve Státní dumě v roce 2015 najevo, že není spokojen se třiceti čtyřmi hodinami, které pro něj ministerstvo vzdělávání vyčleňuje. Podle jeho názoru je to pro zformování pravoslavného cítění u dětí málo, a proto by tento předmět měl být vyučován ve všech trídách a možná i na vysoké škole (Gund’ajev 2015). ${ }^{25}$ Církev v roce 2015 nabídla do ruských školních programů ještě povinný předmět „Mravní základy rodinného života“ (TASS 2015), který se v současnosti vyučuje v některých regionech Ruska a v Petrohadu. ${ }^{26}$

V roce 2009 patriarcha vyjádřil obavu z možnosti zavedení předmětu sexuální výchova do škol, a proto došlo $\mathrm{k}$ důležitému setkání patriarchy s představiteli Jednotného Ruska. Jeho výsledkem byla dohoda, že Jednotné Rusko bude s RPC konzultovat návrhy zákonů (BBC 2009). Tento konkrétní krok ukazuje na sílu politické pozice církve, která dokáže prostřednictvím vládní strany a byrokratického aparátu ovlivňovat podobu přijímaných zákonů a podněcovat projednávání nových norem, jejichž přijetí církev požaduje. Tato pozice je natolik

\footnotetext{
${ }^{24}$ Výjimku tvoři Tatarstán, kde se kvưli náboženské heterogenitě obyvatelstva vyučují pouze „základy světových náboženských kultur“ a „světská etika“. Takový postoj vlády v Tatarstánu ale vyvolává pobouření RPC (Antonov 2016). Na druhou stranu v regionech, kde většinu obyvatelstva tvoří etničtí Rusové, je předmět „Základy pravoslavné kultury“ de facto povinným; pro více informací viz např. Andrejeva (2015).

${ }^{25}$ Vzniká dojem, že patriarcha občas zapomíná nejen na to, že „Základy pravoslavné kultury“ jsou jen jedním z předmětů celého bloku, ale i na to, že podle představ Medveděva, který schválil zavedení tohoto bloku do škol, by předmět neměl vnucovat dětem víru, ale pouze je seznamovat s kulturou, kterou náboženství nese.

${ }^{26}$ Poslední zmínku v tomto ohledu zaslouží i to, že od roku 2015 během přijímacích zkoušek na většině moskevských univerzit začali pracovat pravoslavní duchovní, kteří by měli dát požehnání uchazečům (Avetisjan a Korčmarek 2015), což fakticky ukazuje na zvýhodněné postavení RPC a faktickou nerovnost představitelů všech ruských konfesí.
} 
silná a církev díky ní může ovlivňovat (a reálně i ovlivňuje) výkon politiky takovým způsobem, že nám to umožňuje hovořit o církvi jako o poručnickém aktérovi. Je zároveň nutné zdůraznit, že takové dohody mezi jinými významnými politickými stranami a jinými konfesemi v Ruské federaci, alespoň formálně, neexistují. A je zřejmé, že taková dohoda není zcela v souladu s ústavním ustanovením o oddělení církve a státu. Tato dohoda přinesla církvi výhodnou pozici, což se později projevilo nejen v tom, že (z pohledu církve) nevhodné předměty zavedeny nebyly, ale i v přijetí zákonů o hanobení pocitu věrících (viz níže) a zákazu LGBT propagandy.

Tichá podpora Jednotného Ruska byla patrná i díky v ruském prostředí nepř́lišs známému dokumentu s názvem „Mravní základ modernizace“, který vytvořil Národní institut rozvoje současné ideologie, jenž je považován za think tank strany Jednotné Rusko. V úvodu dokumentu autoři odkazují na poselství Medveděva k Federálnímu shromáždění RF z r. 2009 (NIRSI 2010), v němž se mluvilo o modernizaci, ale náboženství nebylo zmíněno ani jednou (Medveděv 2009). Nicméně autorům tohoto dokumentu se podařilo najít $\mathrm{v}$ Medveděvově poselství odkazy na pravoslaví a nabídnout pravoslavnou víru jako oporu státní ideologie a základ modernizace, i když by to znamenalo nutnost obejít ruskou ústavu (pro více informací viz NIRSI nedat.). Ačkoliv tento dokument nevnesl do ruského zákonodárství změny, dobře ukázal církvi, že se může spoléhat na podporu největší ruské politické strany.

Je zřejmé, že se za takovou podporou ze strany statní moci skrývá vděčnost za ospravedlnění politiky Kremlu a kremelských protežé nejen před pravoslavnou veřejností. Vliv církve na veřejnost se s nástupem Kirilla zvyšoval i díky spolupráci s masmédii prostřednictvím nového synodálního oddělení pro vztahy mezi církví a společností, jehož hlavou byl do roku 2015 místopředseda Kirilla v oddělení vnějších církevních vztahů Vsevolod Čaplin. Druhým piliŕřem součinnosti s médii se stalo synodální informační oddělení, do jehož čela se poprvé dostal laik Vladimír Legojda. Obě oddělení byla na konci roku 2015 sloučena. Zmíněné osoby byly i do té doby dobře známé v ruském prostředí jako prostředníci mezi církví, masmédii a společensko-politickými institucemi. Navíc Legojda je doktorem politických věd a profesorem diplomatické školy Ministerstva zahraničních věcí Ruska (MGIMO) a též šéfredaktorem pravoslavného časopisu „pro pochybující“ Foma, který je možné koupit nejen v Rusku, ale také v celém postsovětském prostoru. Nástup těchto lidí na takto důležité pozice signalizoval, že se RPC bude stále více snažit rozšírít svůj názor mezi lidmi, kterým je církev vzdálená. 
Dané instituce přispěly $\mathrm{k}$ tomu, že církev aktivně proniká $\mathrm{i}$ do masmedií, kde je patriarchovi věnována výrazná pozornost. ${ }^{27,28}$ Jednotlivé rozhovory k různým tématům se vysílají $\mathrm{v}$ pořadu „Vesti“ na televizním kanálu „Rossija“ a v pořadu „Vremja“ na prvním kanálu. Patriarchovy cesty, setkání a komentáře k jakýmkoliv společenským a politickým jevům se zpravidla objevují v hlavních elektronických a tiskových médiích. To je poměrně nový fenomén, díky čemuž začala mít církev značný vliv na veřejné mínění (Lunkin 2012: 201).

Kirillovy projevy, na rozdíl od projevů Alexije II., se daleko častěji zaměřují na témata politická místo náboženských, a proto se nelze divit, že jedním z prvků jeho projevů je uklidňování v oblasti sociálních a ekonomických problémů, stejně jako bezprostřední podpora politiky. $V$ podstatě lze všechna prohlášení shrnout do tezí „Bud'te dobřri“ a „Vše bude dobré“. Výhoda je v tom, že informace mírí k jakémukoli člověku, protože se nevyžaduje bezprostřední posluchačova vazba na pravoslaví, a mohou prrinést útěchu všem - od chudých lidí po oligarchy (Lunkin 2012: 205). Např́íklad v letech 2009-2010 patriarcha přesvědčoval ruské občany o možnosti překonání hospodářské krize na základě mravních principů a morálky (Lunkin 2012: 205-206). Místo kritiky sociální politiky státu vyzýval učitele ve školách k sebeobětování a nezištné službě (Lunkin 2012: 205). V tomto roce se po celém Rusku konaly antikrizové bohoslužby, o kterých se zmiňovala všechna masmédia. ${ }^{29}$ Od Kirilla je možné slyšet proslovy týkající se všech možných témat - od př́čin ekonomické krize (Gund'ajev 2009) ${ }^{30}$ a havárie v Černobylu (Lenta.ru 2011) až po nepochopení zvýšení cen pohanky (Chovanskaja 2015).

Zvláštní místo v činnosti patriarchy má udílení církevních vyznamenání, kterými legitimizuje a ospravedlňuje činnost kremelských protežé (Solodovnik 2013: 19). Jasným dokladem je vztah mezi patriarchou a bývalým gubernátorem Krasnodarského kraje (později ministrem zemědělstvî) Alexandrem Tkačovem. Tomu v roce 2014 udělil patriarcha církevní rád ctihodného Sergije Radoněžského, který se uděluje státním a veřejným činitelům za zásluhy na upevnění a podpoře míru a přátelství mezi národy (MKRU 2014), což je v př́padě Tkačova zajímavé, protože je znám svými vystoupeními proti lidem neruské národnosti (Bederov 2002: 7; Juga.ru 2012). Není jasné, zda patriarcha o takových

\footnotetext{
${ }^{27}$ Kirill je zastáncem myšlenky, že církev může hovořit o všem a vměšovat se do všech veřejných záležitostí, a to až do tvorby právních předpisů. Podle patriarchova názoru je to jediná možnost, jak z církve vytvořit vlivnou společenskou sílu (Solodovnik 2013: 18).

${ }^{28} \mathrm{~S}$ nástupem Kirilla se na federálních kanálech zvýšil i počet pořadů o pravoslaví. Navíc v srpnu roku 2015 byl do kina uveden první ruský pravoslavný kreslený film.

${ }^{29}$ Poslední dobou i státní činitelé vyzývají k nutnosti bojovat s ekonomickou krizí modlitbami. Naprŕklad samarský gubernátor vyzval občany, aby se modlili za to, aby stát byl schopen za pět let platit penze (Gazeta.ru 2015).

${ }^{30}$ Církev vstupuje i do ekonomiky: vytvořila „etický kodex pravoslavného byznysmena“ (Šarapov a Ulybyševa 2012) vyzývá k vytvoření pravoslavného finančního systému (Rusnovosti 2015), Účetní komora RF podepsala s RPC smlouvu o společném boji s korupcí (Interfax 2015a).
} 
projevech Tkačova nevěděl, ale lze se domnívat, že ocenění bylo Tkačovovi uděleno za Olympiádu v Soči a v neposlední řadě za pozici, kterou zaujal Krasnodarský kraj během zesílení proticírkevních nálad od konce roku 2011 do poloviny roku 2012 (viz níže). ${ }^{31}$ Vysoká církevní vyznamenání dostávají nejen političtí činitelé, které zř̌ejmě podporuje Kreml, ale i lidé z mediální sféry. $\mathrm{Na}$ konci roku 2014 takový řád získali kremelští propagandisté Dmitrij Kiseljov a Oleg Dobrodějev (RPC MP 2014).

Patriarchova politizace se projevuje nejen ve vnitřní politice RF, ale iv zahraniční politice Ruska, kde je zřejmá touha patriarchy mít větší vliv v postsovětském prostoru. Patriarcha je zastáncem myšlenky Svaté Rusi, která je ztotožněná s myšlenkou označovanou jako „russkij mir“. Podle patriarchy se RPC může vměšovat do vnitřní a vnější politiky států tvořící Svatou Rus, kam podle něj patří Rusko, Ukrajina, Bělorusko, Moldavsko (RPC MP 2010a) a Kazachstán (RPC MP 2010b), což opět ukazuje na tendenci, respektive alespoň snahu chovat se jako poručnický aktér, $\mathrm{v}$ tomto př́padě dokonce jako (ve vztahu k režimům, na jejichž ovlivňování cílî) poručnický aktér externí. Proto se nelze divit, že v roce 2009 během své návštěvy Běloruska patriarcha při setkání s prezidentem A. Lukašenkem konstatoval, že církev je vždy připravena být prostř̌edníkem mezi běloruským a ruským vedením (RPC MP 2009b). ${ }^{32} \mathrm{~V}$ současnosti se to velice dobře projevuje v souvislosti s konfliktem na východě Ukrajiny, ${ }^{33}$ který má podle slov patriarchy jednoznačně náboženské pozadí a není ničím jiným, než snahou puŕíznivců Ukrajinské řeckokatolické církve a Ukrajinské pravoslavné církve Ukrajinského patriarchátu porazit na Ukrajině kanonické pravoslaví (OVCS MP 2014a). Ve svém vánočním poselství v roce 2015 vyzýval věrící, aby se modlili za národ Rusi na Ukrajině, který se trápí kvůli tomu, že někdo chce kvůli svým zájmům rozdělit Svatou Rus (Colás 2015).

V roce 2014 vystoupil patriarcha s projevem, který mimo jiné obsahoval i výzvu, aby se Rusové nebouřili proti politice, která vedla k západním sankcím (Gund’ajev 2014). V roce 2015 se dokonce zmínil o prospěchu západních sankcí, protože nutí Rusy pracovat (Interfax 2015b). ${ }^{34}$ Ale ve většině projevů je patrné jeho znepokojení mravním úpadkem Západu, který už dlouhou dobu trpí hlubokou duchovní krizí (např. RIA Novosti 2009; OVCS MP 2014b;

\footnotetext{
31 Mnoho zdrojů uvádí Krasnodarský kraj jako kraj, ve kterém se konaly nejrozsáhlejší mítinky na podporu církve (Interfax 2012a; Vz.ru 2012), ale podle některých zdrojů byla účast na mítincích placená ze strany krajských úřadů (Solodovnik 2013: 18).

32 Mezi lety 2004 a 2009 vztahy mezi Ruskem a Běloruskem procházely značným napětím a řadou konfliktů.

33 Po rozpadu SSSR má RPC s jurisdikcí na Ukrajině problém kvůli existenci Ukrajinské řeckokatolické církve a Ukrajinské pravoslavné církve Ukrajinského patriarchátu, kterou RPC považuje za schizmatickou a není uznána ani jednou z pravoslavných církví.

34 O podobném prospěchu sankcí dříve mluvil Sergej Ivanov (RIA Novosti 2015a). Ale celkem o prospěchu západních sankcí mluvili i Putin (NTV 2014) a Medveděv (RIA Novosti 2015b).
} 
RIA Novosti 2015c), skrze niž se nejen povýšeně dívá na zbytek světa, ale také vyžaduje, aby tento zbytek žil podle západních pravidel, ve kterých není místo pro náboženskou svobodu (RIA Novosti 2015c). Patriarcha také mluví o tom, že se Západ přestal ztotožňovat s kréréanskou tradicí (Micheev 2015), což vedlo k tomu, že třeba otevřené nošení kř́žžku může vést k ztrátě zaměstnání (Gund’ajev 2016). A proto se podle patriarchy není možné divit tomu, že Západ je na rozdíl od Ruska lhostejný k osudu křest’anů Blízkého Východu (Interfax 2015c). Podle Kirilla Rusko svou operací v „,sousední Sýrii““ nejen ochraňuje svou vlast, ${ }^{35}$ ale také zachraňuje obyvatele Blízkého Východu, mezi kterými je hodně křest'anů (Gund'ajev 2016). ${ }^{36}$ Letošní historické setkání papeže s ruským patriarchou také bylo řadou zdrojů vnímáno jako snaha Ruska ospravedlnit svo̊j zásah v Sýrii (např. Miroff a Murphy 2016; Soldatov 2016) a zlepšit svou politickou image na Západě (např. Braterskij 2016; Winfield 2016).

V souvislosti s osobností patriarchy je důležité zmínit, že formálně může být patriarcha považován také za vysokého státního úředníka. Od začátku patriarchátu totiž doprovázejí Kirilla zaměstnanci Federální služby ochrany (FSO), což bylo do začátku roku 2011 v rozporu se zákonem o státní ochraně, podle něhož ochrana FSO mohla být poskytována pouze vysokým politickým činitelům (Novaja Gazeta 2012). Když se tato informace objevila v Novoj gažetě, bylo toto postavení legitimizováno vnesením jednoho pozměňovacího návrhu do zákona o státní ochraně, dle něhož FSO může ochraňovat i osoby jako je patriarcha. Takový postoj ruské úřady vysvětlily množstvím výhrůžek, které patriarcha dostává od „bojovných ateistů“ (vojinstvujuščcich ateistov) ${ }^{37}$ (Novaja Gazeta 2012). Změna zůstala s výjimkou Novoj gazety ruskými masmédii nepovšimnuta. Bohoslužby patriarchy jsou dnes doprovázeny zvláštními bezpečnostními opatřeními, včetně rámů detektorů kovů a prohlídek příručních zavazadel; i při běžné bohoslužbě je pak patriarcha doprovázen osobními strážci.

Činnost patriarchy, která odhaluje propojenost mezi církví a Kremlem, vyvolala nejrozsáhlejší znepokojení u řady ruských občanů mezi lety 2011-2012. Tehdy byla zahájena kampaň, kterou patriarcha hodnotil jako velkou kampaň proti církvi (RPC MP 2012, viz též níže).

35 Dřive Putin také hovořil o operaci v Sýrii jako o způsobu ochrany národních zájmů RF (Chrolenko 2015).

36 Čaplin nazval ruskou operaci v Sýrii svatou povinností ruského národa/Ruska bránit lidi (Interfax 2015d), avšak většina západních médií to pochopila tak, že Čaplin nazval ruskou operaci v Sýrii “Svatou válkou” (např. Hearst 2015; AFP 2015 ), což vyvolalo hněv na Blízkém Východě (viz např. BBC 2015; Julaev 2015; The Economist 2015).

37 Ohledně údajných výhrůžek na adresu patriarchy se nemluvilo ani v jednom ruském médiu. Naopak, v té době nejvyšší pravoslavní činitelé podle dostupných zdrojů žádné zřejmé problémy nejspíš neměli, na rozdíl od mulláhů, na které bylo podniknuto poměrně velké množství atentátů (RIA Novosti 2010). Dodnes ovšem ruský muftí ochranku placenou státem nemá. 


\section{c. RPC a její role ve volbách 2011-2012}

V letech 2011 a 2012 vyhrálo v parlamentních volbách Jednotné Rusko a v prezidentských Putin, který se tak po premiérské pauze vrátil do nejvyšší funkce v zemi, což vyvolalo protestní reakce, jejichž rozsah byl v Putinově Rusku poměrně nevídaný. RPC byla $\mathrm{v}$ této době $\mathrm{v}$ centru veřejné debaty, protože podpora poskytovaná Putinovi patriarchou a velkou skupinou duchovních, stejně jako útoky duchovních na protestující, přilákaly pozornost velké části obyvatel Ruska. Změna veřejných nálad podnítila i dosud mlčící věrící k politické aktivitě, což nemohlo u církve a patriarchy vyvolat nadšení (Solodovnik 2012: 32).

Je třeba zmínit, že oficiální církevní hlasy se ještě před volbami vyslovovaly pro to, aby volby byly zrušeny nebo přinejmenším doba vládnutí byla výrazně prodloužena $^{38}$ (Golovko a Smirnov 2011). První oficiální prohlášení po parlamentních volbách zazněla, když byly protestní nálady proti falšování voleb teprve $\mathrm{v}$ počáteční fázi, a šlo o spiše opatrná prohlášení. Legojda ve svém rozhovoru pro Interfax uvedl, že církev vždy byla a bude pro pravdu, proto je nesmírně důležité, aby politická moc pravdu našla, protože pouze tak bude schopná ukázat svou úctu k volbě národa (Interfax 2011). Názor řadových duchovních se rozdělil. Např́klad duchovní církve při Moskevské státní univerzitě uvedl, že studenti, kteří participují na mítincích, nevědí, co dělají, a pochyboval, že cestou demokratických voleb lze alespoň něco vyřešit (Pravmir 2011). Ozvaly se ale i církevní hlasy podporující protestující (více např. Golovko a Mitrofanov 2011; Ljudogovskij 2011; Iljašenko 2011).

Patriarcha zachovával mlčení, což vedlo k tomu, že nejaktivnější účastníci protestů navrhli provést na internetu akci „Požádej patriarchu, at’ odhalí volební lži“ (Otstavnych 2011). ${ }^{39}$ Až 17. prosince patriarcha po bohoslužbě v katedrále Krista Spasitele vystoupil s kontroverzním projevem, ve kterém prohlásil, že pravda vlastně neexistuje, a proto lidé na mítincích bojují za pravdy, které jsou pravdami s malým p. Zdůraznil, že podobné protestní události už dovedly Rusko k velkým problémům v roce 1917 a v devadesátých letech 20. století. Připomněl tedy paralelu se situacemi, které vedly k oslabení ruské mocenské pozice i vnitřních poměrů. Patriarcha také vyjádřil obavu, že ve skutečnosti nespokojenost lidí není ničím jiným než jejich pýchou a touhou po moci, přičemž takoví lidé chtějí zničit ruský národ (Gund’ajev 2011). Slova patriarchy našla ihned odezvu v proslovech jiných církevních činitelů. Čaplin souhlasil se slovy patriarchy

\footnotetext{
38 Jeden z představitelů jako důvod uváděl například to, že „opravdové“ volby už proběhly, čehož dưkazem je skutečnost, že stát dobře funguje - není tedy třeba konat volby nové a prezident i Duma mohou fungovat dále. Jejich funkční období může být prodlouženo na 15 , ale ideálně na 30 let. Jako poněkud svérázný př́klad vhodnosti takto dlouhého období byla uvedena údajně prospěšná vláda Ivana IV. Volby, které by přinesly změnu, by nutně vedly k nestabilitě, která byla přirovnána ke stavu afrických zemí.

39 Se stejnou žádostí se 16. ledna 2012 na patriarchu obrátil otevřeným dopisem Berezovskij (Berezovskij 2012); RPC tento dopis nazvala provokací (Lipič 2012).
} 
ohledně boje za pravdy a navíc zdůraznil, že lidé za ně bojující jsou manipulátory, kteří nutí ostatní bez ohledu na jejich vưli hrát cizí hru (Čaplin 2011). Církevní hlasy podporující protestující se až na několik výjimek přestaly objevovat. Duchovní Dmitrij Sverdlov, nejhlasitěji protestující proti výsledkům voleb, byl oficiálními církevními místy odsouzen a později mu byl zakázán výkon služby. Sverdlov považoval svůj názor ohledně voleb za jeden $z$ důvodů tohoto zákazu. Jako druhý uváděl svůj postoj ohledně kauzy Pussy Riot, opět protikladný k oficiálnímu názoru církve (Zagvozdina 2013).

Patos projevů většiny církevních činitelů neznamenal nic jiného, než že církevní hierarchy zajímají možné volební podvody mnohem méně než potřeba ukázat svou loajalitu existující světské moci, jejíz legitimita pro RPC také nebyla podstatná (Solodovnik 2012: 35). 23. prosince, den před moskevským mítinkem proti falšování voleb, upozornil patriarcha Rusy na nebezpečí sociálních sítí a internetu, s jejichž pomocí byly nejrozsáhlejší protesty opozice organizovány. Svůj postoj Kirill vysvětlil tím, že internet a sociální sítě činí lidi náchylnými k manipulaci (Grove 2011). Toto vysvětlení je však poměrně zvláštní vzhledem $\mathrm{k}$ tomu, že církev sama pro komunikaci s věřícími i širší veřejností sociální sítě aktivně využívá.

Je očividné, že společenské nepokoje zneklidňovaly činitele RPC, v důsledku čehož už v polovině ledna Čaplin ve svém LiveJournalu psal o tom, že by bylo dobré, kdyby existovala možnost vytvořit pravoslavnou politickou stranu. Zákon, který zakazuje vytváření politických stran na základě náboženství, navrhl obejít tím, že strana nebude mít v názvu slovo křest’anská či pravoslavná. Zajímavé je to, že jako př́klad použil západní zkušenost (Čaplin 2012a), avšak ve většině svých projevi̊ samotný Západ považuje za špatný. Caplin sice propagoval vznik takové strany, respektive stran, ale zároveň zdůraznil, že církev a patriarcha takové strany podporovat nebudou, protože pro RPC si jsou všechny strany rovny (Čaplin 2012a). Všemožných pravoslavných/křest’anských stran se nakonec objevilo několik, např. Národní strana většiny (Narodnaja partija bolšinstva), Strana desatera božích přikázání (partija desjati zapovedèj) nebo Ruský křest’anský společensko-politický svaz (Rossijskij christianskij ob̌rčstvenno-političeskij sojur) (Solodovnik 2012: 37-39). Čaplin zapomněl na svůj vlastní výrok o ne-podpoře ze strany církve a začal se aktivně setkávat s vưdci těchto stran a vyjednávat, jaká by měla být jejich stranická ideologie (Solodvnik 2012: 38). V roce 2015 Kirill nakonec veřejně odmítl možnost existence pravoslavné strany oficiálně spojené s církví, avšak prohlásil, že RPC bude podporovat všechny strany, které sdílejí její světonázor (Interfax 2015e). Na konci roku 2012 RPC sice nezrušila synodální usnesení zakazující pracovníkům církve zúčastňovat se voleb, ale na druhou stranu dovolila svým pracovníkům zúčastnit se voleb tehdy, když bude církev ohrožena (Rojzman 2012), což je extrémně vágní usnesení, které se dá volně vykládat a snadno (zne)užít. 
Bez ohledu na to, že na začátku roku 2012 patriarcha prohlásil, že církev nemůže vystupovat na straně té či jiné politické síly, protože její slovo nemůže být politicky zabarvené (Ria.ru 2012), objevilo se později nejen odsouzení opozice (Gund'ajev 2012a), ale i prímá podpora Putina, např. v podobě setkání náboženských činitelů s Putinem organizované patriarchou (Gund'ajev 2012b). ${ }^{40}$ Se žádným jiným kandidátem se ale oficiální představitelé RPC během daného období nesetkávali. Nicméně př́mou agitaci za Putina si na rozdíl od svého duchovního otce archimandrita Ilii, který v Kazaňské katedrále v Petrohradě vyzval duchovní, aby z ambonů nabádali lidi hlasovat pro Putina, patriarcha nedovolil (Nozdrin 2012). ${ }^{41}$

\section{d. Skandály s patriarchou, Pussy Riot a zákon o hanobení pocitů věřících}

Chování církevních představitelů během občanských nepokojů vyvolalo v znepokojené ruské společnosti vlnu proticírkevních nálad. Mezi zastánci demokratických změn, kteři předtím neměli nic proti Kirillovi a jeho spolupracovníkům, vyvolal politický směr patriarchy všeobecné pobouření. Ale patriarcha a jeho okolí záměrně dramatizovali situaci, nazývali ji „informační strategií proti církvi“ a využívali ji k obvinění Západu z podněcování a podpory této činnosti (Melnikov 2012a). Navíc se srovnávali s obět’mi náboženských pronásledování v prvních letech sovětské moci (Filatov 2014: 16).

V tomto období navíc propuklo několik skandálů spojených nejen s církví, ale i prŕmo s patriarchou. $K$ nejznámějším skandálům, které se týkaly patriarchy a objevily se v masmédiích, patři prípad patriarchova bytu v centru Moskvy (pro více informaci viz např. Smirnov a Švarev 2012) a patriarchových hodinek (pro více informaci viz např. Newsru.com 2012). Absurdní skandály zvyšovaly napětí ve společnosti, ale RPC a politici ji podporující reagovali jednoznačně. Čaplin konstatoval, že jde o součást kampaně zaměřené na destabilizaci státu, která vystupuje proti národu, policii, armádě, vládě apod., a v jejím čele je skupinka Rusů sponzorovaná Západem (Loiko 2012). S takovým názorem souhlasil mimo jiné dlouhodobý komunistický předák Gennadij Zjuganov, který doplnil, že kritika RPC je výhodná pro lidi, kteří si nepřejí silné Rusko (RIA Novosti 2012a). Vzhledem k tomu, jakým způsobem se dřrivějš̌i komunistická vláda stavěla k ruské pravoslavné církvi, jsou tato slova z úst komunistického představitele jasným

\footnotetext{
${ }^{40}$ Pro RPC není novým jevem, že její představitel prohlašuje, že církev není politická, ale zároveň podporuje vybrané politiky, čím porušuje usnesení biskupského sněmu. Stejný postoj Alexije II. lze pozorovat během předvolební kampaně v roce 1996.

${ }^{41}$ Slova patriarchy „Chtěli bychom si s vámi promluvit jako s předsedou vlády, ale především jako s kandidátem na funkci prezidenta našeho státu, přičemž s kandidátem, který má, samozřejmě, největší šanci, aby změnil kandidaturu ve skutečnou funkci“ (Gund’ajev 2012b) podle názoru Čaplina agitací nejsou (Rebrov 2012).
} 
důkazem proměny politického klimatu a důležitosti vztahu státu (respektive celkově politické sféry) a církve.

Nejemocionálnější reakce církevních představitelů na ztrátu aureoly svatosti se projevila $\mathrm{v}$ hodnocení vystoupení skupiny Pussy Riot 21. února 2012 v katedrále Krista Spasitele (srov. např. Kalinič a Naxera 2012). ${ }^{42}$ Někteř́ tvrdí, že dívky zazpívaly píseň se slovy urážejícími Putina a patriarchu Kirilla (text viz např. Putna 2015: 280), jiní, že dívky předvedly pouze něco jako pantomimu se skoky a klaněním, ale slova a hudba vznikly až následně a byly pak zveřejněny na internetu (Solodovnik 2012: 41). Názory a interpretace tohoto činu se liší, ale vývoj událostí po této performanci dobře ukazuje reálné propojení státu a církve a také to, jakým způsobem vlivní jedinci reprodukují diskurz, který toto propojení legitimizuje.

Samotné členky Pussy Riot považují své vystoupení za antiklerikální a antimocenské, ale v žádném případě za rouhání (Solodovnik 2012: 41). Církev s takovým hodnocením nemohla souhlasit. Patriarcha celý měsíc mlčel, ale nižší hodnostáři událost aktivně komentovali. Oficiální církevní hlasy od počátku nazývaly vystoupení rouháním, žádaly, aby členky skupiny učinily pokání, avšak zároveň trvaly na tom, že tímto př́padem se musí zabývat pouze světská moc. ${ }^{44} \mathrm{Je}$ nutné zmínit, že na začátku kauzy byli vysocí a řádní náboženští činitelé spíše proti reálnému trestu (pro více informaci viz Pravmir 2012). Církev také zdůrazňovala nemožnost vměšovat se do činnosti jurisdikčních institucí. Ale zklamání nad tím, že členky Pussy Riot neučinily pokání a naopak byly přesvědčeny o tom, že nic špatného církvi neudělaly (Legojda 2012), vedlo k tomu, že představitelé církve čím dál tím více zapomínali na původně deklarované milosrdenství a nemožnost vměšování. Apoteózou „nevměšování byl podle některých zdrojů (Solodovnik 2012: 42-43) dopis generálnímu prokurátorovi Juriji Čajkovi a prokurátorovi Moskvy Sergejí Kuděnějevovi od anonymního „člena iniciační skupiny“, který byl rozeslán do všech moskevských chrámů. Duchovní pak sbírali podpisy pod dopisem, který sami označovali jako iniciativu farníků. Ze splnění tohoto úkolu se měli zodpovídat před arcibiskupem Arsenijem, vikářem

42 Předtím daná skupina učinila něco podobného v Jelochovském chrámu, což ale bylo zcela ignorováno a nemělo to takový dopad na společnost. Podle názoru Čaplina se tak stalo proto, že dívky v Jelochovském chrámu nestihly říct slova urážející pocity věřících (Samsonova 2012b).

43 Tento článek cíleně analyzuje pouze názor vyšších státních a náboženských činitelů. Pro více informací ohledně pozice politicky vlivných „marginálů“ viz Kalinič a Naxera (2012), kteři zmiňují zejména geopolitika Dugina a politického komentátora Sergeje Markova. Ti shodně nabádali $\mathrm{k}$ prísnému potrestání aktérek tohoto vystoupení, které považovali nikoli za nerozvážný čin mladých dívek, ale za promyšlený akt nepřátelství vůči Rusku a vůči ideálu symfonie moci, který je podporován nepřátelskými zahraničními mocnostmi, at' už Západem ( $\mathrm{v}$ prípadě Dugina i Markova) nebo (dle slov Markova) i nepřátelskými státy blízkého zahraničí.

44 Př́kladem může být Čaplin, který danou kauzu od začátku považoval, dle svého blogu, za rouhání (Čaplin 2012b), avšak když poskytoval rozhovory týkající se trestu, o rouhání už nemluvil, ale mluvil o trestném činu, který by měl být potrestán prostřednictvím soudní moci (Čaplin 2012c). 
moskevské eparchie. Někteří duchovní na svých blozích psali, že za odmítnutí účasti jim bylo nabídnuto podat hlášení patriarchovi a odejít do výslužby (Solodovnik 2012: 41-42). Za př́klad „nevměšování lze označit i jeden z projevů Čaplina, který upozornil mocenské orgány, že ti, kdož dívky neodsoudí, mohou přestat spoléhat na podporu pravoslavných (Melnikov 2012a). Názor Kirilla se stal známým až měsíc po přednesení „punkové modlitby“. O tom, jak se pravoslavní činitelé snaží „neovlivňovat průběh vyšetřováni“", se patriarcha nezmínil, ale vyjádř̌il politování nad tím, že někteři pravoslavní rouhání minimalizují, považují ho za nevinné nebo za nějaký vtip. ${ }^{45}$ Patriarcha také zmínil, že Rusko a Rusové nemají budoucnost, jestliže si začnou z velikých ruských svatostí tropit posměch, ospravedlňujíc to jen tím, že je to projev politického protestu (Interfax 2012c).

V tomto kontextu stojí za to se zmínit o „veliké ruské svatosti“, katedrále Krista Spasitele. ${ }^{46} \mathrm{Na}$ rozdíl od oficiálních představitelů církve dívky z Pussy Riot tvrdily, že jejich „modlitba“ se konala na světském místě, v „kanceláŕi RPC“ (Tolokonnikova 2012: 58). Svưj postoj vysvětlovaly tím, že v katedrále Krista Spasitele si je možné pronajmout jakoukoli místnost pro oslavy. Jako prŕḱlad uvedly sál církevních sněmů (Tolokonnikova 2012: 58). Při podrobnějším zkoumání lze v archivu webových stránek katedrály Krista Spasitele nalézt i ceny za pronájem jednotlivých místností z r. 2007 (pro více informace viz FXXS 2007); od té doby byla cena pravděpodobně zvýšena, byt' aktuální ceny nejsou veřejně dostupné. V současnosti se v chrámu běžně konají světská koncertní vystoupení (FXXS 2016).

Podle webových stránek chrám poskytuje zájemcům parkoviště pro 305 aut (FXXS nedat.b), myčku aut, čistírnu (která jako jediná zveřejňuje aktuální ceny) (FXXS nedat.c) a bankomaty. Uvnitř samotné katedrály bývá umístěn inzerát, podle něhož může být po domluvě v katedrále umístěna reklama. ${ }^{47}$ Když skupina

\footnotetext{
${ }^{45}$ Reakce představitelů světské moci byla jednoznačná. Mluvčí Putina Dmitrij Peskov konstatoval, že Putinova reakce byla negativní (RIA Novosti 2012b); Medveděv, v té době stále ještě zastávající funkci ruského prezidenta, $\mathrm{v}$ rozhovoru pro ruské televizní kanály uvedl, že se nebude do rozhodnutí soudu vyjadřovat, ale jako věřící člověk se domnívá, že od daného projevu dívky očekávaly popularitu, které i dosáhly (Interfax 2012b).

${ }^{46}$ Katedrála je největším pravoslavným chrámem na světě a hlavním chrámem ruské ortodoxní církve. Chrám byl otevřen v roce 1883 za vlády bigotního cara Alexandra III. Po bolševické revoluci v roce 1931 byl na základě rozhodnutí Michaila I. Kalinina zdemolován a vyhozen do povětř́, aby uvolnil místo pro výstavbu megalomanského Paláce sovětů (ten byl zamýšlen jako sídlo KSSS a největší budova světa) (Kalinič a Naxera 2012: 34). Velká vlastenecká válka nedovolila palác vybudovat, myšlenka o vybudování paláce byla nakonec zamítnuta $\mathrm{v}$ roce 1956. V roce 1960 zde byl vybudován bazén „Moskva“, který byl na tomto místě do roku 1994. Chrám byl znovu postaven až v letech 1994-2000.

47 Podle oficiálních zdrojů (FXXS 2015) je katedrála spravována fondem katedrály Krista Spasitele, s nímž patriarcha spojitost odmítá (avšak podle provozního řádu katedrály je fond zodpovědný kurátorské radě, v jejímž čele je patriarcha Kirill a primátor Moskvy Sergej Sobjanin; srov. FXXS 2014; FXXS nedat.a). Nenáboženskou činnost, kterou katedrála provádí, by bylo možné obhájit tím, že jsou potřeba prostředky na její správu, ale budova chrámu a pưda pod ním nepatři RPC, ale
} 
aktivistů podala žalobu ohledně takové činnosti, která byla považována za necírkevní a o níž navíc není známo, zda je daněna, ruský soud žalobu odmítl (Interfax 2012d), navíc byli aktivisté obviněni z pomluvy (Masjuk 2012). ${ }^{48}$

O této činnosti RPC se mezi věŕícími ve větším měřítku neví, protože takové informace státní média neposkytují, na rozdíl od činu Pussy Riot, který byl $\mathrm{v}$ ruských médiích jednoznačně prezentován pouze jako hanobení pocitů věřících. Stejně tak Putin, který v tu dobu už znovu zastával funkci prezidenta Ruska, v rozhovoru pro RT už po odsouzení členek skupiny Pussy Riot prohlásil, že stát je povinen chránit pocity věŕících (Putin 2012b).

Zde je tř́eba zmínit, kdo jsou oni věrící, jejichž pocity má stát chránit. Oficiálními obět'mi činu Pussy Riot se stali strážci chrámu, pracovnice chrámu a ještě pět návštěvníků (Nikulin a Chomčenko 2012). Ale nejen oni byli považováni za oběti „,modlitby“ Pussy Riot. Obrovská kampaň na podporu pocitů věŕících byla zahájena na internetu, kde „pravoslavní“ aktivisté zveřejnili seznam předpokládaných účastníků „modlitby“. Ve většině komentářù vyzývali „uražení věřící" $\mathrm{k}$ veřejné násilné odplatě. ${ }^{49}$

Výsledkem dané akce nebylo jen odsouzení dívek, ${ }^{50}$ ale i nový fenomén „nepřátel církve“, který zahrnuje nejen všechny, kdo mluvili o drahých hodinkách patriarchy a jeho bytě, ale i ty, kdo odsoudili patriarchu za podporu Jednotného Ruska a Putina, a stejně tak ty, kdo vyzývali patriarchu k přiznání, že př́i volbách docházelo $\mathrm{k}$ podvodům. „Nepřáteli církve“ jsou i ti, kteří se staví proti výuce „Základů pravoslavné kultury“ na školách, př́ípadně nedostatečně respektují patriarchu (Filatov 2014: 16). Kampaň proti „nepřátelům“ byla hlasitě zahájena „manifestací na obranu víry“ 22. dubna 2012, které se podle oficiálních zdrojů zúčastnilo více než 65 tisíc lidí (Samsonova 2012a).

V roce 2013 po skončení aktivní „proticírkevní kampaně“، v masmédiích Putin na zasedání biskupského sněmu prohlásil, že Rusko musí v rámci boje proti

městu, a proto peníze na správu katedrály Krista Spasitele poskytuje i moskevský magistrát (Baryševa a Gladin 2012).

48 Soud žádost aktivistů odmítl, nebot' vycházel z toho, že stanovené ceny jsou dobročinnými příspěvky. Podle názoru fondu všechno, co je posvěceno, je zboží pro náboženské účely, včetně igelitových sáčkủ. Žádnou nenáboženskou činnost tedy fond nevykonává, což umožnilo obvinit aktivisty z pomluvy (Masjuk 2012).

49 Největší počet vyjádření „věřících“ lze najít na http://namarsh-ru.livejournal.com/ 6606803.html

50 Tři aktérky nakonec byly po pěti měsících vazby moskevským soudem uznány vinnými z „výtržnosti motivované náboženskou nenávistí“ (dívky se rovněž dopustily „zločinného spiknutí za účelem hrubého narušení veřejného pořádku“) a odsouzeny ke dvěma letům internace v nápravné kolonii obecného režimu. Dle prokurátora Alexeje Nikoforova navíc činy pachatelek prokázaly evidentní nenávist a nepřátelství vưči náboženství a „urazily Boha“ (Kalinič a Naxera 2012). 
deficitu „duchovních spon“ (duchovnyje skerepy) ${ }^{51}$ upustit od vulgárního a primitivního chápání sekularismu. Takové opuštění „vulgárního, primitivního chápání sekularismu“ “52 má podle Putina zahrnovat spolupráci mezi církví a státem v oblasti sahající od podpory rodiny a mateřství, výchovy a vzdělávání dětí až po spolupráci v oblasti mládežnické politiky, řešení sociálních problémů a posilování vlasteneckého ducha ruských ozbrojených sil (Chimšiašvili 2013). ${ }^{53}$

Boj s deficitem duchovních spon vedl k tomu, že v létě roku 2013 byl príjat zákon o hanobení pocitů věřících. Zákaz veřejných akcí, umíst'ování textů a obrázků, které uráží pocity věŕících, a to nejen v chrámech a v objektech, které jsou určené pro náboženské účely (jak to bylo stanoveno platnými právními předpisy), ale nyní také kdekoliv po celé zemi, porušuje základní práva občanů na svobodu myšlení a projevu, názoru a informací, které jsou garantovány v čl. 29 ústavy RF. Podle daného zákona tak může i ateistická propaganda být činností, která zákon porušuje, na rozdíl od patriarchova kázání na federálních kanálech; stejně tak se mohou dostat do vězení všichni organizátoři demonstrací proti propojenosti církve a státu. To neznamená nic jiného než to, že daný zákon ochraňuje jen jednu skupinu lidí, věřící, a tím porušuje ke všemu i čl. 14 ruské ústavy. ${ }^{54}$ Lze se domnívat, že daný zákon chrání církev před všemi pro ni nevhodnými vyjádřeními v mediích, tím pádem napomohl Kremlu zajistit úplnou loajalitu církve a patriarchy v budoucnu a také se stal nástrojem $\mathrm{k}$ ochraně vztahů mezi politikou a církví před útokem zvnějšku (Jarzyńska 2013). To, že se podařilo prosadit takovouto zákonnou normu, která dokáže církev účinně chránit před jejími „nepráteli“, opět ukazuje na sílu pozice této instituce, de facto i na její poručnický charakter.

${ }^{51}$ Pojem „duchovní spony“ poprvé použil Putin ve své řeči k Federálnímu shromáždění 12. ledna 2012. Putin tehdy prohlásil, že ruská společnost má zřejmý deficit duchovních spon, což znamená, že má deficit všeho toho, co vždy dělalo Rusy silnějšími a bylo předmětem národní sebeúcty (Putin 2012a).

52 Putin ale neupřesnil, zda „vulgární pojetí sekularismu“ bude zmíněno v ruské ústavě, protože de facto svým prohlášením garant ústavy porušil 14. článek ústavy a zákon z roku 1997 „O náboženských organizacích“.

53 Již za prezidenta Medveděva v roce 2009 bylo schváleno zavedení institutu vojenských duchovních (Lipič 2010).

${ }^{54}$ V letech 2014 a 2015 se v médiích neobjevovaly informace o odsouzení za hanobení pocitů věŕících, i když, jak uvádí výzkum Sova centra (Sibireva 2015), žalob bylo více než v předcházejících letech. Žaloby podali jen pravoslavní aktivisté a týkaly se jak vystoupení zahraničních skupin, tak i místních akcí. Úředníci a organizátoři se většinou snažili co nejvíce vyhovět požadavkům věřících, a to tak, aby záležitost nebyla řešena soudně. Ale od začátku roku 2016 se v médiích častěji objevují informace o odsouzení lidí za hanobení pocitů věřících (pro více informací viz např. Borodjanskij 2016 nebo Rosbalt 2016), přičemž v jednom z prípadů byla za urážku věřících považována i věta „bůh neexistuje“ pronesená v rámci v diskuse na internetu (viz např. Puškarjov 2016). 


\section{Závěrem}

Předložená studie si kladla za cíl zmapovat podobu vztahů církve a státu po zvolení Kirilla moskevským patriarchou a zjistit, v jakých oblastech především dochází ke spolupráci mezi církví a státem a jeho institucemi a představiteli, prričemž důraz jsme kladli na to, jakými zpo̊soby církev posiluje a upevňuje svoje společenské a politické postavení, respektive to, jakým zpo̊sobem v tomto ohledu církvi napomáhá stát. Vztahy mezi církví a státem v Rusku dnes postoupily do nové etapy. Zatímco na počátku devadesátých let za prezidentství Jelcina a patriarchátu Alexije II. tvořil základ těchto vztahů do velké míry princip nápravy chyb způsobených církvi sovětskou minulostí, v dalších letech je základem uvedených vztahů spíše rozsáhlé zapojení RPC do společenského a politického života země ve jménu její budoucnosti.

Budoucnost Ruska v podobě mladé generace se RPC snaží ovlivňovat svým pronikáním do sféry vzdělání, a to (zatím jen) prostřednictvím výuky předmětu „Základy pravoslavné kultury“, který není jen druhem náboženské výchovy dětí v rámci sekulární školy, nýbrž i kurzem, jenž vykazuje ideologické sklony a z jehož náplně plyne, že pravoslaví je jediná směrodatná a vedoucí síla v celých dějinách Ruska: Síla, která Rusko formuje, dává mu vnitřní myšlenku a odlišuje jej od Západu. Církev se ale nezajímá pouze o vzdělání. Fakticky od nástupu Kirilla RPC stále výrazněji proniká do všech sfér života nejen věřících, čemuž napomáhá změna církevního jazyka, který se v rostoucí míře podobá spíše jazyku politickému a umožňuje obracet se i na ty, kdo o křest'anství téměř nic nevědí a nezajímají se o něj. Rostoucí vliv RPC na společnost, který je aktivně podporován ze strany státních institucí, dovoluje církvi mluvit o své zvláštní kulturní, společenské a fakticky i politické misi, v jejímž rámci se považuje za lídra schopného sjednotit různorodé skupiny občanů Ruska. Tato touha ovlivnit a sjednotit nejen věř́cí je ve shodě se snahou ruských orgánů nejen pomoci RPC ovlivňovat ruské občany, ale udělat z ní i oporu obnovení jejich patriotických citů.

Dnes je zřejmé, že ruský patriotismus, který je podle Putina ruskou národní myšlenkou (Beloborodova 2016), je založen na protizápadních prvcích. Tento postoj, který zahrnuje odmítnutí všeho západního včetně liberálních hodnot a prohlašuje ruský lid za nositele jedinečného civilizačního kódu, byl hlavní myšlenkou současného patriarchy Kirilla už na počátku 90. let. Postoj mocenských orgánů se tedy shoduje s oficiální pozicí církve. Protizápadní vektor rozvoje Ruska, který RPC mnohokrát označovala za jediný pro Rusko správný, se stále více hodí Kremlu, protože ospravedlňuje a legitimizuje přechod k nové podobě nedemokratické vlády. Proto se nelze divit, že RPC čím dál častěji schvaluje diskutabilní činy státních představitelů, za což jsou jí ze strany státní moci ochotně poskytována značná privilegia (př́stup do školství, do médií, vliv na podobu přijímaných zákonů atd.), díky nimž církev posiluje svoje pozice. Církev výrazným způsobem zasahuje do politického dění a to $\mathrm{v}$ takové míře, že její 
zapojení překračuje rámec toho, že by byla jednou z mnoha zájmových organizací, které se snaží prosadit svůj program, což vše ukazuje na poručnický charakter této instituce. Výše popsaným způsobem posilování vlastních pozic se ale na druhou stranu církev sama staví do částečné závislosti na státu a př́ed nutnost podporovat politický kurz Kremlu, čímž si teprve vysluhuje reciproční podporu ze strany státu. Z toho vyplývá, že světská moc přetváří RPC $\mathrm{v}$ jeden ze svých nástrojů (i když, jak již bylo naznačeno, impulsy $\mathrm{k}$ řadě kroků vychází z prostředí církve, nicméně jde o kroky, které bývají v souladu s linií představ státních institucî), který v očích veřejnosti legitimizuje kroky Kremlu a legitimitu tak dodává celému režimu. Tato činnost ale zároveň čím dál tím více vzdaluje špičky církevní hierarchie samotnému náboženství a jeho principưm.

Tento text nepokryl a ani nemohl pokrýt veškerá témata související se vztahem státu a církve. Stranou našeho zájmu zůstala řada tematických oblastí, které tak představují široký prostor pro další výzkum. Ten přitom může být poměrně originální, nebot' vztah těchto aktérů není doposud př́liš zkoumán nejen $\mathrm{v}$ rámci českých sociálních věd, ale poněkud paradoxně ani v ruském prostředí. Z témat, která se nabízejí pro hlubší analýzu a která byla $\mathrm{v}$ tomto textu jen stručně načrtnuta, patři bezpochyby financování církve - jak prostřednictvím veřejných prostředků ( $v$ textu jsme zmínili např́klad problematické restituce), tak př́spěvků ze soukromého sektoru (prostých věrících i darů bohatých podnikatelü), ale i z vlastních rozsáhlých (a v některých př́padech poměrně kontroverzních) ekonomických aktivit církve (výše jsme uvedli např́klad ekonomické využití prostor chrámu Krista Spasitele), príčemž zásadním tématem může být analýza napojení církve na ne úplně transparentní zdroje financování. Za druhý rozsáhlý okruh, který byl $\mathrm{v}$ textu jen okrajově zmíněn, je pak možné považovat zahraničněpolitickou dimenzi vztahu státu a církve, respektive vliv a úlohu pravoslaví v prosazování ruské zahraniční politiky. Poslední z linií výzkumu, které bychom rádi zmínili, je analýza vzájemného vztahu z pohledu státu - tedy do jisté míry opačná perspektiva, než jaká byla využita $\mathrm{v}$ rámci tohoto textu, který se soustředil spíše na zpracování tématu optikou církve. Stranou našeho zájmu tedy do určité míry zůstalo využití církve ze strany státní moci jako víceméně jedné z institucí, které jsou součástí mocenského uskupení kolem Putina. Tuto perspektivu přitom považujeme pro pochopení fungování mocenských vztahů v současném Rusku za nemálo důležitou.

\section{Literatura a prameny}

AFP (2015): „Russian church: The fight in Syria is a 'holy war'“" Al Arabiya, 30. 9. 2015, on-line (http://english.alarabiya.net/en/News/middle-east/2015/09/30/Church-saysRussia-fighting-holy-battle-in-Syria.html), [ověřeno k 15. 2. 2016]. 
Andrejeva, Naděžda (2015): „Eto podryv obstanovki v našej straně“. Novaja Gažeta, 24. 4. 2015, on-line (http://www.novayagazeta.ru/society/68238.html), [ověřeno k 15. 2. 2016].

Antonov, Kirill (2016): „Religioznyj diskurs.“ Kommersant, 10. 2. 2016, on-line (http://www.kommersant.ru/doc/2912570), [ověřeno k 15. 2. 2016].

Avetisjan, Roksana a Natalja Korčmarek (2015): „Postupajuščim v vuzy dadut blagoslovenije „dežurnyje“ svjaščenniki.“ Izvestia, 22. 6. 2015, on-line (http://izvestia.ru/news/587964), [ověřeno k 15. 2. 2016].

Balík, Stanislav a Jiří Hanuš (2013): Katolická církev v Ceskoslovensku 1945-1989. Brno: Centrum pro studium demokracie a kultury.

Baturin, J. M. et al. (2003): Jelcinova epocha 1988-2000. Praha: Knižní klub.

BBC (2009): „Frakcija „Jedinoj Rossii” pojdet za sovjetom v RPC“. BBC, 9. 7. 2009, online (http://www.bbc.co.uk/russian/russia/2009/07/090709_church_duma), [ověřeno k 15. 2. 2016].

BBC (2015): „Christiane v Syrii razgnevany slovami RPC o „svjaščennoj borbě“.“ BBC, 6. 10. 2015, on-line (http://www.bbc.com/russian/news/2015/10/151006_syria_ christians_holy_war), [ověřeno $\mathrm{k}$ 15. 2. 2016].

Bederov, Igor (2002): „Nezakonnaja familija“. Novaja Gazeta, 11. 7. 2002, s. 7-8.

Beloborodova, Olesja (2016): „Putin rasskazal ob istinnoj roli patriotizma." V zgljad, 4. 2. 2016, on-line (http://vz.ru/politics/2016/2/4/792180.html), [ověřeno k 15. 2. 2016].

Berezovskij, Boris (2012): „Otkrytoje pismo Predstjatelju russkoj pravoslavnoj cerkvi Patriarchu Kirillu." Echo Moskyy, 16. 1. 2012, on-line (http:/ / echo.msk.ru/blog/berezovski/849154-echo/), [ověřeno k 15. 2. 2016].

Besançon, Alain (2015): Svatá Rus. Brno: Centrum pro studium demokracie a kultury.

Bičurin, Alexej (2000): „Blagoslovlenije na prezidenstvo.“ Nezavisimaja gazeta, 17. 5. 2000, on-line (http://www.ng.ru/facts/2000-05-17/1_blessed.html), [ověřeno k 15. 2. 2016].

Bílek, Jaroslav (2015): „Poručnické síly v Československu 1945-1948.“ Politické vedy 18(1): 124-150.

Boček, Pavel (2011): „Rus na cestě k ruskému pravoslaví،“ Studia historica Brunensia 58(1): 3-9.

Borisov, Timofej, Brynceva, Galina a Adilja Zaripova (2009): „Narečenije Patriarcha.“ Rossijskaja Gazeta, 29. 1. 2009, on-line (http://www.rg.ru/2009/01/29/kirill.html), [ověřeno k 15. 2. 2016].

Borodjanskij, Georgij (2016): „Omskogo studenta prigovorili k ispravitelnym rabotam za comment o Merlin Mensoně." Novaja Gažeta, 30.5.2016, on-line (http://www.novayagazeta.ru / news/1703845.html), [ověřeno k 28. 6. 2016].

Braterskij, Alexadr (2016): „Sankcii ne polučili katoličeskogo blagoslovenija." Gazeta.ru, 12. 2. 2016, on-line (http://www.gazeta.ru/politics/2016/02/11_a_8070149.shtml), [ověřeno k 15. 2. 2016].

Byčkova, Olga, Kurajev, Andrej, Smirnov, Mark a Alexandr Ščipkov (2009): „Vybory Patriarcha Vseja Rusi." Radio Echo Moskvy, 28. 1. 2009, on-line (http://echo.msk.ru/programs/beseda/568719-echo/), [ověřeno k 15. 2. 2016].

Colás, Xavier (2014): „Pulso por Ucrania desde los altares.“ El MUNDO, 20. 4. 2014, online (http://www.elmundo.es/internacional/2014/04/20/5354270322601d3e398b4572. html), [ověřeno k 15. 2. 2016]. 
Čaplin, Vsevolod (2009): „Patriarch Kirill. Reformator ili konservator? Novyje vyzovy i staryje problemy." Stolica. fm., 2. 2. 2009, on-line (http://stolica.fm/archiveview/684/1/), [ověřeno $\mathrm{k}$ 15. 2. 2016].

Čaplin, Vsevolod (2011): „Protojerej Vsevolod Čaplin o falsifikacii vyborov.“ Pravmir, 28. 12. 2011, on-line (http://www.pravmir.ru/protoierej-vsevolod-chaplin-o-falsifikaciivyborov/), [ověřeno k 15. 2. 2016].

Čaplin, Vsevolod (2012a): „Nužna li, vozmožna li „pravoslavnaja“/ „christianskaja partija"“?" Livejournal.com, 1. 11. 2012, on-line (http://pravoslav-pol.livejournal. com/2012/01/11/), [ověřeno k 15. 2. 2016].

Čaplin, Vsevolod (2012b): „Koščunstvo u Carskich vrat.“ Livejornal.com, 22. 2. 2012, online (http://pravoslav-pol.livejournal.com/8714.html), [ověřeno k 15. 2. 2016].

Čaplin, Vsevolod (2012c): „Prot. Vsevolod Čaplin: Akcija v Chramě Christa Spasitelja javnoje narušenije Administrativnogo kodexa." Pravmir.m, 21. 2. 2012, on-line (http://www.pravmir.ru/prot-vsevolod-chaplin-akciya-v-xrame-xrista-spasitelyayavnoe-narushenie-administrativnogo-kodeksa/), [ověřeno k 15. 2. 2016].

Čaplin, Vsevolod (2014): „Světlyj večet s protojerejem Vsevolodom Čaplinym.“ Radio Véra, 17. 11. 2014, on-line (http://radiovera.ru/svetlyiy-vecher-s-protoiereemvsevolodom-chaplinyim-efir-ot-17-11-2014.html\#.VG3AvnhdarX), [ověřeno k 15. 2. 2016].

Černjaev, Anatolij (2010): „Patriarch Kirill kak novyj Nikon.“ NG Religija, 3. 2. 2010, online (http://www.ng.ru/ng_religii/2010-02-03/4_kirill.html), [ověřeno k 15. 2. 2016].

Džorajeva, Svetlana V. (1997). Gosudarstvenno-cerkov'nyje otnošenija v Rossii (opyt filosofskoistoričeskogo analiza). Moskva: Rossijskaja akademija gosudarstvennoj služby pri prezidente RF (disertační práce).

Federálni zákon RF č.125/1997, ze dne 26. záru 1997 o svobodé sovesti $i$ o relogioznych objedinenijach.

Federální zákon RF č.327-FZ/2010, ze dne 30. ríjna 2010 o peredače religioznym orgaizacïam umušcestva religioznogo naznačenija, nachodjaščegosja v gosudarstvennoj ili municioalnoj sobstvennosti.

Fiala, Petr (2007): Laborator sekularizace. Brano: Centrum pro studium demokracie a kultury.

Filatov, Sergej (2014): „Russkoje pravoslavije, obščestvo i vlast vo vremena političeskoj turbulentnosti. RPC posle oseni 2011.“ In: Alexej Malašenko a Sergej Filatov, Montaそ̌ i demontaž sekuljarnogo mira. Moskva: ROSSPEN, 9-41.

FOM (2008): „Smert' Patriarcha Alexija II.“ FOM, 14. 12. 2008, on-line (http://bd.fom.ru/report/cat/rel_rel/patriarchy/d085010), [ověřeno k 15. 2. 2016].

FXXS (2007): „Prejskurant platnych uslug.“ FXXS, 24. 5. 2007, on-line (http://web.archive.org/web/20070524043948/http://www.fxxc.ru/price/price_rent. php), [ověřeno k 15. 2. 2016].

FXXS (2014): „Dokumenty.“ FXXS, 27. 3. 2014, on-line (http://www.fxxc.ru/other/1.php), [ověreno k 15. 2. 2016].

FXXS (2015): „O Fondě.“ FXXS, 1. 1. 2015, on-line (http://www.fxxc.ru/), [ověřeno $\mathrm{k}$ 15. 2. 2016].

FXXS (2016): „Meroprijatija.“ FXXS, 1. 1. 2016, on-line (http://fxxc.ru/rent/16.php), [ověřeno k 15. 2. 2016]. 
FXXS (nedat.a): „Spisok Regionaloj obščestvennoj organizacii sodějstvija razvitijuj komplexa Chrama Christa Spasitelja „Sovět popečitělej Chrama Christa Spasitelja“.“ FXXS, nedat., on-line (http:// fxxc.ru/about/sovet.php), [ověřeno k 15. 2. 2016].

FXXS (nedat.b): „Podzemnyj garaž.“ FXXS, nedat., on-line (http://www.fxxc.ru/rent/parking.php), [ověřeno k 15. 2. 2016].

FXXS (nedat.c): „Chimčistka." FXXS, nedat., on-line (http://www.fxxc.ru/drycleaning/), [ověřeno k 15.2. 2016].

Gazeta.ru (2015): „Samarskij gubernator prizval molit’sja za vyplatu pensij.“ Gazeta.ru, 18. 6. 2015, on-line (http://www.gazeta.ru/social/news/2015/06/18/ n_7300941.shtml), [ověřeno k 15. 2. 2016].

Gilbert, Leah a Payam Mohseni (2011): „Beyond Authoritarianism: The Conceptualization of Hybrid Regimes." Studies in Comparative International Development 46(3): 270-297.

Gladin, Evgenij a Elena Baryševa (2012): „Biznes-centr Christa Spasitelja.“ Moskovskij novosti, 23. 4. 2012, on-line (http://www.mn.ru/society/faith/80472), [ověreno k 15. 2. 2016].

Golovko, Oksana a Dmitrij, Smirnov (2011): „Protoierej Dmitrij Smirnov: Ja protiv

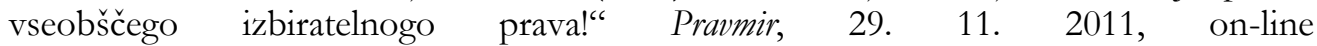
(http://www.pravmir.ru/protoierej-dimitrij-smirnov-ya-protiv-vseobshhego-

izbiratelnogo-prava/), [ověřeno k 15. 2. 2016].

Golovko, Oksana a Georgij, Mitrofanov (2011): „Protoierej Georgij Mitrofanov: My vidim okončatelnuju diskreditaciju idei vybornoj vlasti.“ Pravmir, 5. 12. 2011, on-line (http:/ / www.pravmir.ru/protoierej-georgij-mitrofanov-my-vidim-okonchatelnuyu-

diskreditaciyu-idei-vybornoj-vlasti/), [ověřeno k 15. 2. 2016].

Grove, Thomas (2011): „Russia church head warns against Internet before rally.“ Reuters, 24. 12. 2011, on-line (http://www.reuters.com/article/2011/12/23/us-russia-patriarchinternet-idUSTRE7BM10N20111223), [ověřeno k 15. 2. 2016].

Gund'ajev, Vladimir (2005): „Zamysel Božij o čelověkě i svoboda voli: eschatologičeskaja perspektiva." RPC MP, 15. 11. 2005, on-line (http://www.patriarchia.ru/ $\mathrm{db} /$ text/57597), [ověřeno k 15. 2. 2016].

Gund'ajev, Vladimir (2007): „Vystuplenije mitropolita Smolenskogo i Kaliningradskogo Kirilla, predsedatelja Otdela vnešnich cerkovnych svjazej Moskovskogo Patriarchata na Konferencii religioznych liderov." Moskovskaja Patriarchija, 6. 6. 2007, on-line (https://mospat.ru/archive/36508.htm), [ověřeno k 15. 2. 2016].

Gund’ajev, Vladimir (2009): „Svjatějšij Patriarch Kirill: „Odna iz pričin globalnogo krizisa - uvlečenije neoliberalnymi idejami v oblasti ekonomiki““. RPC MP, 30. 10. 2009, online (http://www.patriarchia.ru/db/text/923926.html), [ověřeno k 15. 2. 2016].

Gund’ajev, Vladimir (2011): „Propoved’ Svjatějšego Patriarcha Kirilla v deň pamjati velikomučenicy Varvary v Chramě Christa Spasitelja.“ RPC MP, 17. 12. 2011, on-line (http://www.patriarchia.ru/db/text/1837473.html), [ověřeno k 15. 2. 2016].

Gund’ajev, Vladimir (2012a): „Slovo Svjatějšego Patriarcha Kirilla v tretju godovščinu intronizacii vChrame Christa Spasitelja." RPC MP, 1. 2. 2012, on-line (http://www.patriarchia.ru/db/text/1992020.html), [ověřeno k 15. 2. 2016].

Gund'ajev, Vladimir (2012b): „Stenogramma vstreči predsedatelja Pravitelstva RF V.V.Putina so Svjatějšim Patriarchom Kirillom i liderami tradicionnych religioznych 
obščin Rossii.“ RPC MP, 8. 2. 2012, on-line (http://www.patriarchia.ru/db/text/ 2005767.html), [ověřeno k 15. 2. 2016].

Gund’ajev, Vladimir (2014): „Slovo Svjatějšego Patriarcha Kirilla v prazdnik Kazanskoj ikony Božijej Materi v Uspenskom Sobore Moskovskogo Kremlja.“ RPC MP, 4. 11. 2014, on-line (http://www.patriarchia.ru/db/text/3826012), [ověřeno k 15. 2. 2016].

Gund’ajev, Vladimir (2015): „Vystuplenije Svjatějšego Patriarcha Kirilla na otkrytii III Roždestvenskich Parlamentskich vstreč." RPC MP, 22. 1. 2015, on-line (http://www.patriarchia.ru/db/text/3960558.html), [ověřeno k 15. 2. 2016].

Gund’ajev, Vladimir (2016): „Rožděstvenskoje intervju Svjatějšego Patriarcha Kirilla telekanalu „Rossija.“ RPC MP, 7. 1. 2016, on-line (http://www.patriarchia.ru/db/ text/4327642.html), [ověřeno k 15. 2. 2016].

Hanuš, Jiř́ (ed.) (2006): V znik státu jako proces sekularizace. Brno: Centrum pro studium demokracie a kultury.

Hearst, David (2015): „Putin's Holy War in Syria.“ The Huffington Post, 10. 7. 2015, on-line (http://www.huffingtonpost.com/david-hearst/putins-holy-war-in-

syria_b_8256442.html), [ověřeno k 15. 2. 2016].

Holzer, Jan (2001): Politický systém Ruska. Hledáni státu. Brno: Centrum pro studium demokracie a kultury.

Holzer, Jan (2004): Politické strany Ruska. Hledáni identity. Brno: Centrum pro studium demokracie a kultury.

Holzer, Jan (2015): „Nejistá demokratizace: př́pad ruské opozice.“ In: Jiř́ Hanuš (ed.), Rusko a Západ. Eseje o (ne)porozumèní. Brno: Centrum pro studium demokracie a kultury, 85-104.

Chimšiašvili, Polina (2013): „Putin: Nužno ujti ot vulgarnogo ponimanija svetskosti.“ Vedomosti, 1. 2. 2013, on-line (http://www.vedomosti.ru/politics/articles/2013/02/01/ putin_cerkov_nuzhno_dopustit_k_resheniyu_socialnyh_problem), [ověřeno k 15. 2 . 2016].

Chovanskaja, Asja (2015): „Patriarch udivljon rostom cen na grečku.“ KPRU, 7.1.2015, on-line (http://www.kp.ru/daily/26327.2/3209882), [ověřeno k 15. 2. 2016].

Chrolenko, Alexandr (2015): „Vojska RF v Syrii - zaščita nacionalnych interesov Rossii.“ RIA Novosti, 30. 9. 2015, on-line (http://ria.ru/analytics/20150930/1293467896.html), [ověřeno $\mathrm{k}$ 15.2.2016].

Iljašenko, Alexandr (2011): „Protojerej Aleksandr Iljašenko: u menja net doverija k rezultatam vyborov." Pravmir, 5. 12. 2011, on-line (http://www.pravmir.ru/protoierejaleksandr-ilyashenko-u-menya-net-doveriya-k-rezultatam-vyborov/), [ověřeno k 15. 2. 2016].

Interfax (2009): „Pěrěpodgotovka učitělěj po kursu „Duchovno-nravstvennoje vospitanije“ načnětsja zimoj." Interfax, 1. 9. 2009, on-line (http://www.interfaxreligion.ru/buddhism/?act=news\&div=31822), [ověřeno $\mathrm{k}$ 15. 2. 2016].

Interfax (2011): „V Cerkvi sčitajut važnym ustanovit istinu v voprose ob itogach vyborov pravomymi metodami i prizyvajut vozderžatsja ot provokacij.“ Interfax, 9. 12. 2011, online (http://www.interfax-religion.ru/?act=news\&div=43419), [ověřeno k 15. 2. 2016].

Interfax (2012a): „Desjat tysjač čelovek, vozmuščennych pank-molebnom Pussy Riot prinjali učastije v mitinge v Krasnodare." Interfax, 31.3.2012, on-line (http://www.interfax.ru/russia/238641), [ověřeno k 15. 2. 2016]. 
Interfax (2012b): „Medveděv: Pussy Riot rasčitovali na popularnost i polučili jejo.“ Interfax, 26. 4. 2012, on-line (http://www.interfax.ru/russia/242942), [ověřeno k 15. 2. 2016].

Interfax (2012c): „Patriarch Kirill nazval akciju Pussi Riot nasmjeskoj djavola.“ Interfax, 26. 3. 2012, on-line (http://www.interfax-religion.ru/?act=news\&div=44747), [ověřeno k 15. 2. 2016].

Interfax (2012d): „OZPP ne udalos osporit' zakonnost' torgovli na territorii chrama Christa Spasitelja." Interfax, 14. 9. 2012, on-line (http://www.interfaxreligion.ru/?act=news\&div=47683), [ověřeno $\mathrm{k} 15.2$. 2016].

Interfax (2015a): „Cerkov' i Sčetnaja palata budut vmestje borot'sja s korrupcijej i ekstrjemizmom.“ Interfax, 24. 7. 2015, on-line (http://www.interfaxreligion.ru/?act=news\&div=59558), [ověreno $\mathrm{k} 15.2 .2016$ ].

Interfax (2015b): „Patriarch Kirill uvjeren v polze antirossijskich sankcij.“ Interfax, 21. 9. 2015, on-line (http://www.interfax-religion.ru/?act=news\&div=60246), [ověřeno k 15. 2. 2016].

Interfax (2015c): „Patriarch Kirill uprekaje Zapad v bezrazličii k učasti christian Bližnjego Vostoka." Interfax, 10. 11. 2015, on-line (http://www.interfaxreligion.ru/?act=news\&div=60887), [ověřeno $\mathrm{k} 15.2$. 2016].

Interfax (2015d): „V RPC nazvali svjaščennym dolgom Rossii spasenije Sirii ot terrorizma." Interfax, 7. 10. 2015, on-line (http://www.interfax.ru/russia/471829), [ověřeno k 15. 2. 2016].

Interfax (2015e): „Patriarch Kirill zajavil ob otsutstvii u RPC političeskich ambicij.“ Interfax, 11. 12. 2015, on-line (http://www.interfax.ru/russia/484612), [ověreno k 15. 2. 2016].

ISR 2050 (nedat.): „OAZT MES.“ ISR 2050, nedat., on-line (http://isr2050.ru/items101.htlm), [ověreno $\mathrm{k}$ 15. 2. 2016].

Jarzyńska, Katarzyna (2013): „Russkaja pravoslavnaja cekov’ kak čast' gosudarstva i obščestva.“ Zurnalnyj $\quad$ zal, $15 . \quad 12 . \quad 2013, \quad$ on-line (http://magazines.russ.ru/nz/2013/4/10ya.html), [ověřeno k 15. 2. 2016].

Juga.ru (2012): „Reč gubernatora Kubani o kazačjej policii, migrantach i sudbach Rodiny.“, Juga.ru, 2. 8. 2012, on-line (http://www.yuga.ru/articles/society/6390.html), [ověřeno k 15. 2. 2016].

Julaev, Salavat (2015): „Slova RPC o „svjaščennoj vojně“ vyzvali gněv u syrijskich christian." Golos Islama, 7. 10. 2015, on-line (http://golosislama.com/ news.php?id=27950), [ověřeno k 15. 2. 2016].

Kalinič, Petr a Vladimír Naxera (2011): „Politická teorie a geopolitika A. G. Dugina.“ Rexter 13(2): 31-56.

Kirillov, Nikolaj (2007): „Cerkovnaja restitucija.“ Kommersant, 18.6.2007, on-line (http://www.kommersant.ru/doc/774401), [ověřeno k 15. 2. 2016].

Knox, Zoe (2005): Russian Society and the Orthodox Church. Religion in Russia after communism. London: Routledge.

Korobov, Pavel (2009): „Mir - narodam, zemlja - christianam.“ Kommersant, 24. 2. 2009, on-line (http://www.kommersant.ru/doc/1125186), [ověřeno k 15. 2. 2016].

Korobov, Pavel, Timošinov, Jevgenij, Lesovskich, Igor a Natalja Bašlykova (2010): „Cerkvi pripomněli kazjonnoje dobro.“ Kommersant, 20.12.2010: 5. 
Krasikov, Alexej (2000): „Konstitucionnyj Sud i svoboda sověsti v Rossii.“ Konstitucionnoje pravo: Vostočnoevropèjskoje obozrènije 1(30): 234-237.

Kratochvíl, Petr (2011): „Analýza role římskokatolické církve při spoluutváření české zahraniční politiky. "Mezinárodni vataby 46(2): 20-34.

Krug, Pavel (2009): „VIP-mirjani i fenomem Daniila.“ Novaja Gazeta, 15. 1. 2009, on-line (http://www.ng.ru/politics/2009-01-15/3_kartblansh.html), [ověřeno k 15. 2. 2016].

Kuzmenkova, Olga (2013): „Perezagruzka pravoslavija.“ Gazeta.ru, 1. 2. 2013, on-line (http://www.gazeta.ru/politics/2013/02/01_a_4950005.shtml), [ověřeno k 15. 2. 2016].

Legojda, Vladimir (2012): „,Vladimir Legojda: „Reakcija na vychodku Pussy Riot - eto test na zrelost' graždanskogo obščestva." Pravmir, 7. 3. 2012, on-line (http:/ / www.pravmir.ru/vladimir-legojda-reakciya-na-vyxodku-pussy-riot-eto-test-nazrelost-grazhdanskogo-obshhestva/), [ověřeno k 15. 2. 2016].

Leichtová, Magda (2010): Pod maskou medvéda. Neporozumèni ve vztazich Ruska a Západu po skončeni studené války. Brno: Václav Klemm.

Lenta.ru (2011): „Patriarch Kirill nazval pričinu Černobylskoj avarii.“ Lenta.ru, 27. 4. 2011, on-line (http://lenta.ru/news/2011/04/27/zagrehi/), [ověřeno k 15. 2. 2016].

Linz, Juan (2000): Totalitarian and Authoritarian Regimes. Boulder: Lynne Rienner Publishers.

Lipič, Olga (2012): „V RPC nazvali pismo Berezovskogo patriarchu provokacijej.“ Ria.ru., 17. 1. 2012, on-line (http://ria.ru/society/20120117/541692766.html), [ověřeno k 15. 2. 2016].

Ljudogovskij, Feodor (2011): „Vybory po farisejski.” Pravmir, 7. 12. 2011, on-line (http://www.pravmir.ru/vybory-po-farisejski/), [ověřeno k 15. 2. 2016].

Lobačev, Sergej (2003): Patriarch Nikon SPb: Iskusstvo-SPb.

Loiko, Sergej L. (2012): „Russian Orthodox Church is in spiritual crisis, critics say.“ Los Angeles Times, 22. 4. 2012, on-line (http://articles.latimes.com/2012/apr/22/world/lafg-russia-church-scandal-20120422), [ověreno k 15. 2. 2016].

Lunkin, Roman (2012): „Obraz PRC v svetskich massmedia: meždu mifom o gosudarstvennoj cerkvi i folklorno-okkultnym pravoslavijem." In: Alexej Malašenko a Sergej Filatov, Pravoslavnaja cerkov' pri novom patriarche. Moskva: ROSSPEN, 171-223.

Malašenko, Alexej (2011): „Nacionalizm rukovodstva Russkoj pravoslavnoj cerkvi v pervom desjatiletii XXI veka." Carnegie, 27. 1. 2011, on-line (http://carnegie.ru/events/?fa=3177), [ověřeno k 15. 2. 2016].

Masjuk, Elena (2012): „Izdelije osveščeno. Obměnu i vozvratu ne podležit.“ Novaja Gareta, 21. 9. 2012, on-line (http://www.novayagazeta.ru/politics/54541.html?p=365), [ověřeno k 15. 2. 2016].

Medveděv, Dmitrij (2009): „Poslanije Federalnomu Sobraniju Rossijskoj Federacii.“ Prezident Rossii, 12. 11. 2009, on-line (http://www.kremlin.ru/events/president/ transcripts/5979), [ověřeno k 15. 2. 2016].

Melnikov, Andrej (2012a): „Ne patriašeje eto delo?“" Nezavisimaja gazeta, 4. 4. 2012, on-line (http://www.ng.ru/events/2012-04-04/1_patriarh.html?insidedoc), [ověřeno k 15. 2. 2016].

Melnikov, Andrej (2012b): „Proščenija ne budět.“ Nezavisimaja gazeta, 27. 2. 2012, on-line (http://www.ng.ru/politics/2012-02-27/3_kartblansh.html), [ověřeno k 15. 2. 2016]. 
Micheev, Alexej (2015): „Zapad perestajet byt’ chrisitanskim.“ RIA Novosti, 28. 10. 2015, on-line (http://ria.ru/religion/20151028/1309500233.html), [ověřeno k 15. 2. 2016].

Miroff, Nick a Brian Murphy (2016): „Meeting of pope and patriarch highlights ancient rifts, current fears." The Washington Post, 12. 2. 2016, on-line (https:/ /www.washingtonpost.com/world/meeting-between-pope-and-patriarchhighlights-ancient-rifts-and-current-worries/2016/02/12/e7780868-d199-11e5-b2bc988409ee911b_story.html), [ověřeno k 15. 2. 2016].

MKRU (2014): „Tkačeva nagradili orděnom Sergija Radonežskogo.“ MKRU, 6. 10. 2014, on-line (http://kuban.mk.ru/articles/2014/10/06/tkacheva-nagradili-ordenom-sergiya radonezhskogo.html), [ověřeno k 15. 2. 2016].

Newsru.com (2012): „Bloggery obnaružili čudo na fotografijach Patriarcha - usčezajut časy." Newsru.com, 4. 4. 2012, on-line (http://www.newsru.com/religy/04apr2012/ uhr.html), [ověřeno k 15. 2. 2016].

Nikulin, Pavel a Julia Chomčenko (2012): „Sledovateli zaveršili „pank-moleben“.“ Moskovskije novosti, 5. 6. 2012, on-line (http://www.mn.ru/incidents/accident_court/ 81822), [ověřeno k 15. 2. 2016].

NIRSI (nedat.): „Nravstvennaja osnova modernizacii.“ NIRSI, nedat., on-line (http://www.nirsi.ru/48), [ověřeno k 15. 2. 2016].

Nižegorodcev, Denis (2009): „Missioner po prizvaniju.“ V zgljad, 30. 1. 2009, on-line (http://vz.ru/society/2009/1/30/251743.html), [ověřeno k 15. 2. 2016].

Novaja Gazeta (2007): „Politika RPC: konsolidacija ili razval strany.“, Novaja Gazeta, 23. 7. 2007, on-line (http://old.novayagazeta.ru/data/2007/kentavr03/00.html), [ověřeno k 15. 2. 2016].

Novaja Gazeta (2012): „Spasut i sochranjat.“ Novaja Gazeta, 20. 5. 2012, on-line (http://www.novayagazeta.ru/politics/52694.html), [ověřeno k 15. 2. 2016].

Nozdrin, Ilija (2012). Propoved' v Kazanskom Sobore. (https://www.youtube.com/ watch?v $=$ TbNtSqlqEuw\&feature $=$ youtu.be), [ověřeno k 15. 2. 2016].

NTV (2008): „Medveděv: končina Patriarcha - ogromnoje gore dlja strany.”, NTV, 5. 12. 2008, on-line (http://www.ntv.ru/novosti/145815/), [ověřeno k 15. 2. 2016].

NTV (2014): „Putin rasskazal o polze zapadnych sankcij dlja Rossii.“ NTV, 15. 11. 2014, on-line (http://www.ntv.ru/novosti/1263402/), [ověřeno k 15. 2. 2016].

Otstavnych,Valerij (2011): „Provjedjom akciju v seti „Poprosi Patriarcha obličit lož vyborov“!' Echo Moskyy, 8.12.2011, on-line (http://echo.msk.ru/blog/otstavnih/ 837209-/), [ověřeno k 15. 2. 2016].

OVCS MP (2014a): „Svjatějšij Patriarch Kirill prizval predstojatelej pomestnych cerkvej vozvysit golos v zaščitu pravoslavnych christian Vostoka Ukrajiny.", OVCS MP, 14. 8. 2014, on-line (https://mospat.ru/ru/2014/08/14/news106782/), [ověřeno k 15. 2. 2016].

OVCS MP (2014b): „Sostojalas vstreča Svjatějšego Patriarcha Kirilla s predsedatelem upravlenija po dělam religij Tureckoj Respubliki.“, OVCS MP, 12. 12. 2014, on-line (https://mospat.ru/ru/2014/12/12/news112918/), [ověřeno k 15. 2. 2016].

Papkova, Irina (2011): „Russian Orthodox concordat? Church and state under Medvedev." Nationalities Papers 39(5): 667-683. DOI: 10.1080/00905992.2011.602394

Pravmir (2011): „Miting: za ili protiv.“ Pravmir, 8. 12. 2011, on-line (http://www.pravmir.ru/miting-za-ili-protiv/), [ověřeno k 15. 2. 2016]. 
Pravmir (2012): „Pank - feministki: kaznit nelzja pomilovat? (mnenija).“ Pravmir, 5. 3. 2012, on-line (http://www.pravmir.ru/pank-feministki-kaznit-nelzya-pomilovatmneniya/), [ověřeno k 15. 2. 2016].

Prus, Justyna (2009): „Nowy patriarcha - Cyryl.“ Rzeczpospolita, 28. 1. 2009, on-line (http://www.rp.pl/artykul/254743.html), [ověřeno k 15. 2. 2016].

Ptáčník, Jan (2012): „Perspektivy využití Linzovy metodologie pro výzkum nedemokracie." Central European Political Studies Review 12(2-3): 315-336.

Puškarjov, Vlad (2016): „Pervyj obvinjaemyj v oskorblenii čuvst verujuščich - o tjurjme i psichuškě." Dožd, 13.3.2016, on-line (https://tvrain.ru/teleshow/bremja_novostej/ delo-405341/), [ověřeno k 28. 6. 2016].

Putin, Vladimir (2012a): „Poslanije Prezidenta Federalnomu Sobraniju.“ Prezident Rossii, 12. 12. 2012, on-line (http://kremlin.ru/events/president/news/17118), [ověřeno k 15. 2. 2016].

Putin, Vladimir (2012b): „Intervju RT.“ RT, 6. 9. 2012, on-line (https://www.youtube.com/watch?v=EmIOWrb51Yc), [ověřeno k 15. 2. 2016].

Putna, Martin C. (2015): Obrazy z. kulturních dějin ruské religiozity. Praha: Vyšehrad.

Rebrov, Dmitrij (2012): „Prot. Vsevolod Čaplin: Patriarch ne agitiroval za Putina.“ Neskućnyj sad, 21. 2. 2012, on-line (http://www.nsad.ru/articles/prot-vsevolod-chaplinpatriarh-ne-agitiroval-za-putina), [ověreno k 15. 2. 2016].

Regions.ru (2007): „Religioznoje obrazovanije v školach dolžno byt' fakul'tativnym.“ Regions. ru, 15. 9. 2007, on-line (http://regions.ru/news/2097535), [ověřeno k 15. 2. 2016].

Reisinger, William M., Hesli, Vicki L. a Ebru Erdem (1999): „The Patriarch and the President: Religion and Political Choice in Russia." Demokratizatsiya 7(1): 42-72.

RIA Novosti (2009): „Zapad pereživajet glubokij duchovnyj krizis, sčitajet patriarch Kirill." RLA Novosti, 19. 4. 2009, on-line (http://old.rian.ru/religion/20090419/ 168606777.html), [ověřeno k 15. 2. 2016].

RIA Novosti (2010): „Slučaji napadenija i ubijstva muftijev na Severnom Kavkaze v 19982010 gg." RIA Novosti, 15. 12. 2010, on-line (http://ria.ru/spravka/20101215/ 309173739.html), [ověřeno k 15. 2. 2016].

RIA Novosti (2012a): „Zjuganov: ataka na RPC vygodna těm, kto ne chočet vidět Rossiju silnoj.“ RIA Novosti, 15. 4. 2012, on-line (http://ria.ru/society/20120415/ 626820635.html), [ověřeno k 15. 2. 2016].

RIA Novosti (2012b): „Press-sekretar Putina nazval otvratitelnym „pank-moleben“ v Chramě." RIA Novosti, 7. 3. 2012, on-line (http://ria.ru/society/20120307/ 586620161.html), [ověřeno k 15. 2. 2016].

RIA Novosti (2015a): „Ivanov: v režimě sankcij jest' plusy, možno požit' v něm i podolše." RIA Novosti, 10. 6. 2015, on-line (http://ria.ru/economy/20150610/ 1069207482.html), [ověřeno k 15. 2. 2016].

RIA Novosti (2015b): „Medveděv: sankcii prostimulirovali Rossiju k vzajimodějstviju s Azijej.“ RIA Novosti, 11. 6. 2015, on-line (http://ria.ru/economy/20150611/ 1069418164.html), [ověřeno k 15. 2. 2016].

RIA Novosti (2015c): „Patriarch: Zapad nachoditsja v glubokom duchovnom krizise.“ RIA Novosti, 17. 6. 2009, on-line (http://ria.ru/religion/20150617/1074442702.html), [ověřeno k 15. 2. 2016].

Ridiger, Alexej (1995). Osnovy pravoslavnogo obrazovanija v Rossii. Moskva: MP. 
Rojzman, Anastasija (2012): „Svjaščennikov v Rossii dopustili do politiky.“ Kommersant FM, 5. 10. 2012, on-line (http://www.kommersant.ru/doc/2037501), [ověřeno k 15. 2. 2016].

Rosbalt (2016): „Saratovskomu žurnalistu grozit presledovanije za oskorblenije čuvstv verujuščich.“ Rosbalt, 4.5.2016, on-line (http://www.rosbalt.ru/russia/2016/05/04/ 1511770.html), [ověřeno k 28. 6. 2016].

RPC MP (2008): „Patriaršije pozdravlenije Dmitriju Medveděvu s pobědoj na prezidentskich vyborach.“ RPC MP, 3. 3. 2008, on-line (http://www.patriarchia.ru/db/ text/373113.html), [ověřeno $\mathrm{k}$ 15. 2. 2016].

RPC MP (2009a): „, Opredelenije „O vzajimootnošenijach Cerkvi s gosudarstvom i svetskim obščestvom na kanoničeskoj territorii Moskovskogo Patriarchata v nastojaščeje vremja." $\quad R P C \quad M P, \quad 18 . \quad 1 . \quad 2009$, on-line (http://www.patriarchia.ru/db/text/530460.html), [ověřeno k 15. 2. 2016].

RPC MP (2009b): „Sostojalas vstreča Svjatějšego Patriarcha Kirilla s Prezidentom. Respubliky Belarus A. G. Lukašenko." RPC MP, 25. 9. 2009, on-line (http://www.patriarchia.ru/db/print/749787.html), [ověřeno k 15. 2. 2016].

RPC MP (2010a): „Svjatějšij Patriarch Kirill: Moldova - neotjemlemaja čast Svjatoj Rusi.“ RPC MP, 21. 8. 2010, on-line (http://www.patriarchia.ru/db/text/1254808.html), [ověřeno k 15. 2. 2016].

RPC MP (2010b): „Predstojatel Russkoj Cerkvi prizval ukrepljat kazačju solidarnost na vsjom prostranstve Svjatoj Rusi." RPC MP, 1. 9. 2010, on-line (http:/ /www.patriarchia.ru/db/text/1265739.html), [ověřeno k 15. 2. 2016].

RPC MP (2012): „Obraščenije Vysšego Cerkovnogo Sověta Russkoj Pravoslavnoj Cerkvi.“ RPC MP, 3. 4. 2012, on-line (http://www.patriarchia.ru/db/text/ 2135736.html), [ověřeno k 15. 2. 2016].

RPC MP (2014): „Svjatějšij Patriarch Kirill udpstojil generalnogo direktora VGTRK O.B.

Dobrodějeva i generalnogo direktora MIA „Rossia segodnja“ D.K.Kiseljova cerkovnych nagrad.“, RPC MP, 22. 12. 2014, on-line (http://www.patriarchia.ru/db/ text/3887269.html), [ověřeno k 15. 2. 2016].

Rusnovosti (2015): „Čaplin predlagajet sozdat' pravoslavnuju finansovuju sistěmu.“ Rusnovosti, 28. 7. 2015, on-line (http://rusnovosti.ru/posts/381267), [ověreno k 15. 2. 2016].

Ryžakov, Michail; Žurin, Alexej; Filonov, Georgij a Svetlana, Gudilina (2009): „Recenzija Rossijskoj akaděmii obrazovanija na rukopis učebnika Andreja Kurajeva „Osnovy pravoslavnoj kultury“." Portal Credo, 8. 12. 2009, on-line (http://www.portalcredo.ru/site/?act=news\&id=74810), [ověřeno $\mathrm{k} 15.2$. 2016].

Samsonova, Olga (2012a): „Bolšinstvo učastnikov molitvennogo stojanija - moskviči, otmečajut v RPC." RIA Novosti, 23. 4. 2012, on-line (http://ria.ru/religion/20120423/ 632884317.html), [ověřeno k 15. 2. 2016].

Samsonova, Olga (2012b): „RPC: Chram Christa Spasitelja ne pervyj, gde vystupili Pussy Riot.“ RIA Novosti, 17. 3. 2012, on-line (http://ria.ru/society/20120317/ 598430640.html), [ověřeno k 15. 2. 2016].

Sebencov, Andrej (1998). Federalnyj zakon „O svobodě sovesti $i$ o religioznych objedinenijech“: sodeř̌anie i suščnost (kommentarii). Moskva: Mysl'. 
Sekerák, Marián (2014): „Dávid a Goliáš: Spolu alebo proti sebe? Bilaterálne vzt’ahy Svätej stolice a USA v kontexte medzinárodnej politiky." Acta Fakulty filozofické Západočeské univerzity v Plzni 6(3): 52-84.

Semjonov, Vladimir (2012): „Vozrastanije roli Russkoj Pravoslavnoj Cerkvi v obščestvenno-političeskoj žizni Rossii na ruběže tysjačeletij.“ Vlast’ 10(2012): 143147.

Sibireva, Olga (2015): „Problemy realizacii svobody sověsti v Rossii v 2014 godu.“ Sova center, 1. 4. 2015, on-line (http://www.sova-center.ru/religion/publications/2015/04/ d31644/\#Toc383943616), [ověřeno k 15. 2. 2016].

Smirnov, Leonid a Alexandr Švarev (2012): „Patriaršaja kvartira - kamen pretknovenija dlja juristov." Rosbalt. 30. 3. 2012, on-line (http://www.rosbalt.ru/moscow/2012/ 03/30/963780.html), [ověřeno k 15. 2. 2016].

Soldatov, Alexandr (2016): „Bezuslovnaja piar poběda Kirilla.“ Novaja Gazeta, 13. 2. 2016, on-line (http://www.novayagazeta.ru/society/71836.html), [ověřeno k 15. 2. 2016].

Solodovnik, Svetlana (2012): „Dva naroda, dvě cerkvi.“ Pro et Contra 3(55): 32-61.

Solodovnik, Svetlana (2013): „Rossija: oficialnaja cerkov’ vybiraet vlast.“ " Pro et Contra 3-4 (59): 6-26.

Solženicyn, Aleksander (1995): „The Russian Question“ and the End of the Twentieth Century. New York: Farra, Straus and Giroux.

Taratuta Julia (2009b): „Bez lišnich bogoslovov.“ Kommersant. 16. 1. 2009, 6.

Taratuta, Julia (2009a): „Poměstnyj razdor.“ Kommersant. 22. 1. 2009, 6.

Taratuta, Julia a Pavel Korobov (2008): „Svjato město opustělo.“ Kommersant, 8. 12. 2008, 1

Taratuta, Julia a Pavel Korobov. (2009): „Novyj patriarch prinjal pervoje rešenije.“ Kommersant, 29. 1. 2009, 6.

TASS (2015): „RPC predlagajet vključit’ v školnuju programmu kurs „Nravstvenyje osnovy semejnoj žizni“." TASS, 26. 5. 2015, on-line (http://tass.ru/obschestvo/ 1994642), [ověřeno k 15. 2. 2016].

The Economist (2015): „Russia, Syria and holy war.“ The Economist, 21. 10. 2015, on-line (http://www.economist.com/blogs/erasmus/2015/10/russia-syria-and-holy-war), [ověřeno k 15. 2. 2016].

Tolokonnikova, Naděžda (2012): Pussy Riot. Cto eto bylo? Moskva: Algoritm.

Ústava Ruska 1993, ve znění pozdějších předpisů.

Vedomosti (2009): „Kandidat ot partii vlasti.“ Vedomosti, 22. 1. 2009, on-line (http://www.vedomosti.ru/newspaper/article.shtml?2009/01/22/178034), [ověřeno k 15. 2. 2016].

Vedomosti (2010): „Světskaja vlast ispolzujet ambicii RPC.“ Vedomosti, 18. 2. 2010, online (http://www.vedomosti.ru/opinion/articles/2010/02/18/svetskaya-vlast-ispolzuet -ambicii-rpc), [ověřeno k 15. 2. 2016].

Velikanov, Pavel (2009). Archijerejskij i Pomestnyj Sobory Russkoj Pravoslavnoj Cerkvi 2009. Moskva: Izvestija.

Vertjanov, Sergej (2012). Obščaja biologija. Sergijev Posad: Svjato-Trojickaja Sergijeva Lavra.

Vološin, Vladimir a Michail Blochin (2009): „Ot Patriarcha Kirilla ždut reform.“ KRRU, 30. 1. 2009, on-line (http://kp.ua/politics/71061-ot-patryarkha-kyrylla-zhdut-reform), [ověřeno k 15. 2. 2016]. 
Výnos Prequidenta RF č.281-rp/1993, ze dne 23. dubna 1993

Vz.ru (2012): „Miting protiv Pussy Riot prošel v Krasnodare.“, V₹.ru, 31. 3. 2012, on-line (http://vz.ru/news/2012/3/31/572170.html), [ověřeno k 15. 2. 2016].

WCIOM (2013a): „K kakomu veroispovjedaniju (konfessii) Vy sebja otnositje?“, WCIOM, 11. 3. 2013, on-line (http://wciom.ru/zh/print_q.php?s_id=922\&q_id= 63692\&date $=11.08 .2013$ ), [ověřeno $\mathrm{k}$ 15. 2. 2016].

WCIOM (2013b): „Po Vašemu mneniju, dopustimo ili net, čtoby prezidentom Rossii byl čelověk, ispovedujuščij otličnuju ot pravoslavija religiju?“, WCIOM, 27. 10. 2013, online (http://wciom.ru/zh/print_q.php?s_id=933\&q_id=64367\&date=27.10.2013), [ověřeno k 15. 2. 2016].

Winfield, Nicole (2016): „'Finally': Pope meets Russian Orthodox leader.“ Associated Press, 12.2. 2016, on-line (http://bigstory.ap.org/article/5bb15e8174984e379ea734efb71ef7c4 /pope-departs-cuba-first-stop-mexico), [ověřeno k 15. 2. 2016].

Zagvozdina, Darja (2013): „Sistema vypljovyvajet těch, kogo ne smogla perevarit'، Gareta. ru, 16. 1. 2013, on-line (http://www.gazeta.ru/social/2013/01/16/4928265. shtml), [ověřeno k 15. 2. 2016].

Zubec, Olga (2010): „Ekspertnaja ocenka originala-makěta učebnika „Osnovy světskoj etiki“" 4-5 kl. Bondarenko L.I., Pěrov V.J." Institut filosofii Rossïjskoj Akadèmii Nauk, 1. 1. 2010, on-line (http://iph.ras.ru/page50562154.htm), [ověřeno k 15. 2. 2016].

\section{Transformations in the relationship between the Russian Orthodox Church and the state in the times of the patriarch Kirill}

\section{SUMMARY}

The goal of this paper is to explore the activities of the Russian Orthodox Church and its standing in the political and social life of post-Soviet Russia in recent years. It will aim to analyze relations between politics, the Russian Orthodox Church, and society in the era following the election of Patriarch Kirill in 2009. The paper puts this topic into historical context and deals with the specific Russian relationship between religious and secular power. Relations between the Church and the state in Russia today have entered a new era. If we reason that these relations at the beginning of the 1990s (the era of Boris Yeltsin's presidency and Alexy II's patriarchy [patriarch from 1990 to 2008]) were based on the principle of "merely" correcting the wrongs done to the Church under Soviet rule, then the following years (mainly after Kirill I was chosen head of the Church and Vladimir Putin became President) were marked by extensive inclusion of the Russian Orthodox Church in the social and political life of the country in the interests of the future of Russia.

The Russian Orthodox Church is now striving to take charge of the future of the countrÿ and its younger generation by permeating into the sphere of education via the creation of school subjects such as "The Basics of the Orthodox Church", which is not 
only a form of religious education for children in otherwise secular schools, but also a school subject that attempts to fill the role of a course in ideology. On this basis, we may reason that the Orthodox religion is perceived as the only authoritative driving force in the whole of Russian history. The Russian Orthodox Church, however, is concerned with more than just the education of children. Following Kirill's nomination, the Church has begun to penetrate into all areas of the lives of Russian citizens, whether they are religious or not. This has been fostered by transformations in the language of the Church, which has deviated toward a more political register and has empowered the Church to reach out to those who know almost nothing of Christianity and would otherwise have no interest in it. The growing influence of the Russian Orthodox Church in society has allowed the Church to speak out about their unique cultural, social and de facto political mission, in which it proclaims itself a capable leader in unifying diverse groups of Russian citizens. This desire to influence and unify the religious and non-religious corresponds directly to efforts made by the Russian authorities (partially with the help of the Russian Orthodox Church) in influencing Russian citizens as well as in gaining their support regarding the renewal of patriotic sentiment in Russia.

At present, it is evident that Russian patriotism, which, in Vladimir Putin's words, is a "Russian national idea", is based on anti-Western elements. This attitude, which includes the rejection of everything western (including liberal values) and ordains the Russian people as the bearers of a unique civilizational code, has been the main idea of the present patriarch Kirill since the beginning of the 1990s. The stance of the Russian authorities in power has continually been in line with the proclamations of the Russian Orthodox Church. The anti-Western vector of Russian development, which the Russian Orthodox Church has repeatedly proclaimed to be the only true path for Russia, has been playing more and more into the Kremlin's plans, as it justifies and legitimizes the transformation into a new era of undemocratic rule. It is therefore no surprise that the Russian Orthodox Church has been condoning with growing frequency various controversial acts committed by representatives of the state, which in turn is willing to provide the Church with various significant privileges. By entering into such a relationship, however, the Church has put itself in a position of de facto dependence on the Russian state and is forced to support politically the course set by the Kremlin. This shows that secular power in Russia has been transforming the Russian Orthodox Church into one of its various tools, which in turn justifies the steps taken by the Kremlin in the eyes of the public, ensuring the overall legitimacy of the regime. Such a role for the Church, however, will only distance its leaders from their original and actual religious goals and roles. 